\title{
Agostic versus Terminal Ethyl Rhodium Complexes: A Combined Experimental and Theoretical Study
}

\author{
3 Ana M. Geer, José A. López, Miguel A. Ciriano, and Cristina Tejel* \\ 4 Departamento Química Inorgánica, Instituto de Síntesis Química y Catálisis Homogénea (ISQCH), CSIC-Universidad de Zaragoza, \\ 5 Pedro Cerbuna 12, 50009-Zaragoza, Spain
}

6 S Supporting Information

7 ABSTRACT: Ethylene insertion into $\mathrm{Rh}-\mathrm{H}$ bonds in complexes

8 bearing an anionic fac-triphosphane ligand gives hydrido 9 complexes, $\beta$-agostic species, or noninteracting ethyl derivatives 10 depending on the reaction conditions. Several chemical equilibria 11 between these species have been analyzed by NMR and DFT 12 calculations, which revealed that they are mainly controlled by the 13 entropy. Moreover, $\beta$-agostic species were found to be lower in 14 enthalpy than the corresponding hydride-ethylene complexes, 15 probably due to the steric pressure exerted by the bulky fac16 triphosphane ligand.

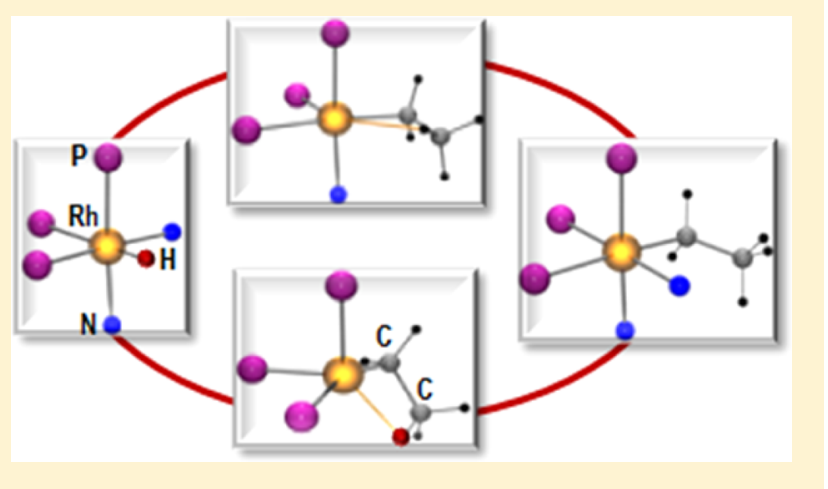

\section{$17 \square$ INTRODUCTION}

18 Weak interactions between nonpolar $\mathrm{C}-\mathrm{H}$ bonds and 19 transition metals have been proved to be of paramount 20 importance in organometallic chemistry and catalysis, con21 tributing to major developments in the field of $\mathrm{C}-\mathrm{H}$ bond 22 activation and/or functionalization processes, ${ }^{1}$ as well as in 23 dehydrogenation reactions. ${ }^{2}$ Both versions, intermolecular $(\sigma$ 24 complexes) and intramolecular (agostic ${ }^{3}$ complexes) are 25 known, the latter being important intermediates connecting 26 two fundamental reactions in organometallic chemistry, namely, 27 the insertion of olefins into $\mathrm{M}-\mathrm{H}$ bonds and the reverse one, 28 the $\beta$-hydrogen elimination. Nowadays, the significance of 29 agostic species becomes evident from the large body of 30 literature in which the multiple roles they can play is 31 enlightened. ${ }^{4}$ As a way of example, $\alpha$-agostic interactions 32 have been proved to have a strong impact on the stereo33 specificity and rate of olefin insertion in polymerization; ${ }^{5} \beta$ 34 agostic species often lead to $\mathrm{C}-\mathrm{H}$ activation reactions, ${ }^{6}$ while 35 the $\gamma$-agostic ones have been reported to be crucial in the 36 stabilization of the propagating species in vinyl norbornene 37 polymerization. ${ }^{7}$ Moreover, a delicate balance between 38 electronic versus steric factors can tip the stability of $\alpha$-versus $39 \beta$-agostic compounds, ${ }^{8}$ or even between $\beta$ - and $\gamma$-agostomers. ${ }^{9}$ 40 Furthermore, longer range interactions such as the rare $\delta$ - and $41 \varepsilon$-agostic ones are involved in uncommon intramolecular 1,4-, 42 metal migration or $1,5-\sigma$ bond metathesis, respectively. ${ }^{10}$ In 43 other instances, they are valuable intermediates connecting the 44 transition states that lead to $\mathrm{C}-\mathrm{H}$ versus $\mathrm{C}-\mathrm{C}$ activation 45 reactions, ${ }^{11}$ and also documented is their participation in the 46 stabilization of highly unsaturated intermediates-such as T47 shaped $\mathrm{d}^{8}-\mathrm{ML}_{3}$ complexes ${ }^{12}$ - requiring two agostic interac48 tions in some cases. ${ }^{13}$
A key feature of these particular M-alkyl moieties can be 49 related to their lability, providing (or not) a vacant site on the 50 coordination sphere of the metal, which, in turn, significantly 51 impacts the reactivity of the complex. Consequently, the study 52 of the dynamics of such species has been the focus of much 53 attention from both experimental ${ }^{14}$ and theoretical ap- 54 proaches, ${ }^{15}$ most of them related to the estimation of the 55 migratory insertion barriers in the context of the polymerization 56 of olefins. $^{16}$

The subtle balance between geometric and electronic effects 58 on the strength of such weak interactions is not evident for late 59 transition metal complexes yet. ${ }^{4 \mathrm{e}}$ Among others, some relevant 60 factors would include electronic characteristics of the metals, ${ }^{17}{ }_{61}$ steric requirements such as the size of substituents on ligands, ${ }^{18} 62$ trans influence, ${ }^{19}$ or solvent effects. ${ }^{20}$

A survey of the literature revealed that rhodium complexes 64 bearing simultaneously hydride and olefin ligands-or their 65 isomeric alkyl-agostic structures-are quite scarce, being 66 limited to $\left[\mathrm{Rh}\left(\mathrm{C}_{2} \mathrm{H}_{4}\right)(\mathrm{H})\left(\mathrm{P}^{\mathrm{i}} \mathrm{Pr}_{3}\right)_{2}\right],{ }^{21}$ cyclopentadienylrhodium 67 complexes, ${ }^{22}$ rhodacarborane species, ${ }^{23}$ and the more recently 68 reported with pincer type ligands. ${ }^{14 \mathrm{~b}, 24}$

Anionic P-based tripodal ligands such as $\mathrm{PhBP}_{3}^{-}\left(\mathrm{PhBP}_{3}{ }^{-}=70\right.$ $\left.\mathrm{PhB}\left(\mathrm{CH}_{2} \mathrm{PPh}_{2}\right)_{3}{ }^{-}\right)$have not been explored before in this field, 71 while they show the additional attractive of labeling three 72 positions in octahedral complexes (by means of the NMR 73 active phosphorus nuclei). Consequently, the " $\mathrm{Rh}\left(\mathrm{PhBP}_{3}\right)$ " 74 scaffold seems to be particularly adequate for the study of 75 dynamics undergone by $\mathrm{Rh}$-agostic species. Additionally, 76 $\mathrm{PhBP}_{3}{ }^{-}$binds strongly to rhodium, ${ }^{25}$ allowing the development 77

Received: January 18, 2016 
78 of a rich chemistry including oxygen activation, ${ }^{26}$ stabilization 79 of unusual tetrahedral environments for rhodium(I), ${ }^{27}$ multiple $80 \mathrm{Rh}=\mathrm{N}$ bonds with imido ligands, ${ }^{28}$ and catalysis such as the 81 selective hydrogenation of $\mathrm{C}=\mathrm{C}$ bonds in $\alpha, \beta$-unsaturated 82 substrates, ${ }^{29}$ and coupling of aldehydes to esters, ${ }^{30}$ both 83 catalyzed by the highly reactive bis(hydride) complex [Rh$\left.84\left(\mathrm{PhBP}_{3}\right)(\mathrm{H})_{2}(\mathrm{NCMe})\right]$. While relevant for catalysis, the easy 85 and fast hydrogen transfer of the hydride ligands in $86\left[\mathrm{Rh}\left(\mathrm{PhBP}_{3}\right)(\mathrm{H})_{2}(\mathrm{NCMe})\right]$ to olefins prevents its use as 87 reagent for the stepwise study of olefin insertion reactions. 88 Therefore, attention was focused on the monohydride version $89\left[\mathrm{Rh}\left(\mathrm{PhBP}_{3}\right)(\mathrm{H})(\mathrm{NCMe})_{2}\right]^{+}\left([\mathbf{1}]^{+}\right)$, straightforwardly prepared 90 by protonation of one of the hydride ligands of $\left[\mathrm{Rh}\left(\mathrm{PhBP}_{3}\right)\right.$ $\left.91(\mathrm{H})_{2}(\mathrm{NCMe})\right]$ in acetonitrile. ${ }^{25 a}$ Complex $[\mathbf{1}]^{+}$combines a 92 single hydride ligand with two labile acetonitrile ligands, 93 making it a valuable precursor for the study of olefin 94 coordination to $\mathrm{Rh}(\mathrm{III})$ species and further insertion reactions. 95 Herein, we report a combined experimental and theoretical 96 study on this topic including a full picture of the fluxional 97 behavior undergone by the $\beta$-agostic complex $\left[\mathrm{Rh}\left(\mathrm{PhBP}_{3}\right)\right.$ $\left.98\left(\mathrm{CH}_{2} \mathrm{CH}_{2}-\mu-\mathrm{H}\right)(\mathrm{NCMe})\right]^{+}\left([3]^{+}\right)$, which in turn, sheds light on 99 the potential dynamics of such species. In addition, the 100 determining role of entropy and steric effects in the migratory 101 insertion of olefins into $\mathrm{M}-\mathrm{H}$ bonds is also reported.

\section{$102 \square$ RESULTS AND DISCUSSION}

103 Energetics for Dissociation of Acetonitrile in Complex $104\left[\mathrm{Rh}\left(\mathrm{PhBP}_{3}\right)(\mathrm{H})(\mathrm{NCMe})_{2}\right]^{+}\left([1]^{+}\right)$. The feasibility for the 105 dissociation of the acetonitrile in complex $\left[\mathrm{Rh}\left(\mathrm{PhBP}_{3}\right)(\mathrm{H})\right.$ $\left.106(\mathrm{NCMe})_{2}\right]^{+}\left([\mathbf{1}]^{+}\right)$- to eventually produce the species $[\mathrm{Rh}-$ $\left.107\left(\mathrm{PhBP}_{3}\right)(\mathrm{H})(\mathrm{NCMe})\right]^{+}\left([2]^{+}\right)$, Figure 1 -was experimentally

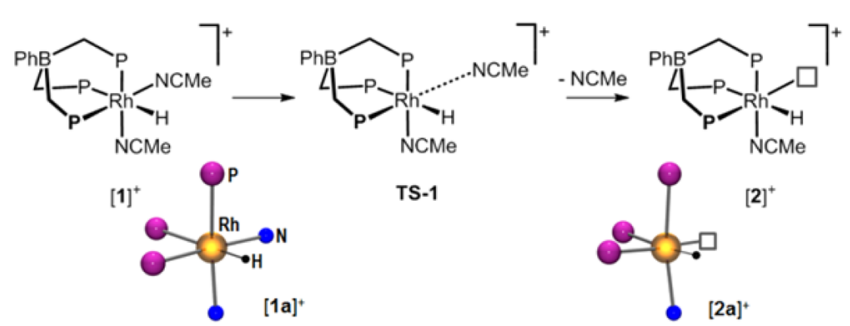

Figure 1. Acetonitrile dissociation from $[1]^{+}$and DFT modeled structures for complexes $[\mathbf{1 a}]^{+}$and $[\mathbf{2 a}]^{+}$. Only the $\mathrm{P}$ atoms of $\mathrm{PhBP}_{3}{ }^{-}$ (purple) and $\mathrm{N}$ atoms of acetonitrile (blue) are shown for clarity.

108 evaluated from the VT- ${ }^{1} \mathrm{H}$ NMR spectra in $\mathrm{d}^{8}$-toluene, a solvent 109 in which $[\mathbf{1}]^{+}$is slightly soluble. On heating, broad-line effects 110 on the signal corresponding to acetonitrile were clearly 111 observable in the ${ }^{1} \mathrm{H}$ NMR spectra. Simulation of the spectra 112 and fitting the chemical exchange rate constants $(k)$ into the 113 Eyring equation gave the activation parameters $\Delta H^{\ddagger}=16.3 \pm 1$ $114 \mathrm{kcal} \mathrm{mol}^{-1}$ and $\Delta S^{\ddagger}=3 \pm 2 \mathrm{cal} \mathrm{mol}^{-1} \mathrm{~K}^{-1}$ (see Supporting 115 Information). In separate experiments, the dependence of $k$ 116 with the concentration of acetonitrile was examined. Values of $k$ 117 were found to be independent of the concentration of $\mathrm{MeCN}$, 118 indicating that they correspond to the rates of acetonitrile 119 dissociation from $[\mathbf{1}]^{+}$. Moreover, the low value for the 120 activation entropy $\left(3 \pm 2 \mathrm{kcal} \mathrm{mol}^{-1} \mathrm{~K}^{-1}\right)$ agrees with a 121 transition state like TS-1, in which the departing acetonitrile is 122 still close to rhodium (Figure 1 ).

123 Complex $\left[\mathrm{Rh}\left(\mathrm{PhBP}_{3}\right)(\mathrm{H})(\mathrm{NCMe})_{2}\right]^{+}\left([\mathbf{1} \mathbf{a}]^{+}\right)$and the 124 pentacoordinated species $\left[\mathrm{Rh}\left(\mathrm{PhBP}_{3}\right)(\mathrm{H})(\mathrm{NCMe})\right]^{+}\left([\mathbf{2 a}]^{+}\right)$ 125 have been studied by DFT methods using the full molecules as models. Stationary points for both complexes were located. The 126 calculated structure for the hydride bis(acetonitrile) complex, 127 $\left[\mathrm{Rh}\left(\mathrm{PhBP}_{3}\right)(\mathrm{H})(\mathrm{NCMe})_{2}\right]^{+}\left([\mathbf{1 a}]^{+}\right)$, shows rhodium in an 128 octahedral geometry while rhodium displays a square pyramid 129 geometry in $[\mathbf{2 a}]^{+}$, as commonly observed for $\mathrm{d}^{6}-\mathrm{RhL}_{5} 130$ compounds. Two protons of the phenyl groups in $[\mathbf{2 a}]^{+}$were 131 found to be placed in close proximity to rhodium (3.339 and 132 $2.907 \AA$ A) providing, probably, some stabilization to this 133 intermediate.

Acetonitrile dissociation from $[\mathbf{1 a}]^{+}$was analyzed by 135 modeling the structures obtained from the separation of one 136 NCMe ligand from rhodium up to $7 \AA$. However, the transition 137 state TS-1 (Figure 1) could not be found since a continuum of 138 energy was obtained with no clear maximum. Nonetheless, the 139 difference in enthalpy between $[\mathbf{1 a}]^{+}$and $[\mathbf{2 a}]^{+}$from DFT was 140 found to be $17.8 \mathrm{kcal} \mathrm{mol}^{-1}$, a value that nicely fits to that 141 experimentally calculated $\left(\Delta H^{\ddagger}=16.3 \pm 1 \mathrm{kcal} \mathrm{mol}^{-1}\right) \cdot 142$ Therefore, extrusion of acetonitrile from $[\mathbf{1}]^{+}$is a feasible 143 process expected to occur at room temperature.

Reactions of Complex $\left[\mathrm{Rh}\left(\mathrm{PhBP}_{3}\right)(\mathrm{H})(\mathrm{NCMe})_{2}\right]^{+}\left([1]^{+}\right) 145$ with Ethylene. Saturation of a $\mathrm{CD}_{2} \mathrm{Cl}_{2}$ solution of $[\mathbf{1}]^{+}$with 146 ethylene at $-30{ }^{\circ} \mathrm{C}$ causes ethylene insertion into the $\mathrm{Rh}-\mathrm{H} 147$ bond to produce an equilibrium with the $\beta$-agostic complex 148 $\left[\mathrm{Rh}\left(\mathrm{PhBP}_{3}\right)\left(\mathrm{CH}_{2} \mathrm{CH}_{2}-\mu-\mathrm{H}\right)(\mathrm{NCMe})\right]^{+}\left([3]^{+}\right)$and acetonitrile 149 (Figure 2). The reaction was found to be reversible, and $150 \mathrm{f} 2$
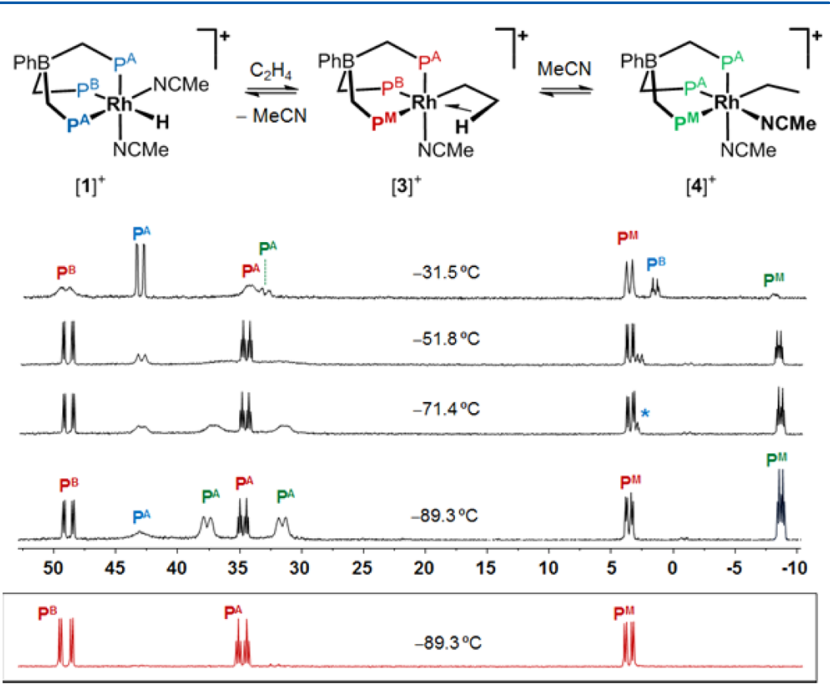

Figure 2. VT- ${ }^{31} \mathrm{P}\left\{{ }^{1} \mathrm{H}\right\}$ NMR spectra of the reaction mixture of the hydride complex $\left[\mathrm{Rh}\left(\mathrm{PhBP}_{3}\right)(\mathrm{H})(\mathrm{NCMe})_{2}\right]^{+}\left([\mathbf{1}]^{+}\right)$with ethylene in $\mathrm{CD}_{2} \mathrm{Cl}_{2}$ (in black). The ${ }^{31} \mathrm{P}\left\{{ }^{1} \mathrm{H}\right\}$ of pure samples of the $\beta$-agostic complex $[3]^{+}$is shown in red (bottom trace) for comparative purposes.

addition of acetonitrile to the reaction mixture fully shifts the 151 equilibrium toward $[\mathbf{1}]^{+}$. On the contrary, no new species were 152 observed after pressurizing the NMR tube with ethylene (3 153 bar). Moreover, no experimental evidence for the hydride 154 ethylene complex $\left[\mathrm{Rh}\left(\mathrm{PhBP}_{3}\right)\left(\mathrm{C}_{2} \mathrm{H}_{4}\right)(\mathrm{H})(\mathrm{NCMe})\right]^{+}$was 155 found even carrying out the reaction at $-90{ }^{\circ} \mathrm{C}$. On the 156 contrary, the related ethylbis(acetonitrile) complex [Rh- 157 $\left.\left(\mathrm{PhBP}_{3}\right)\left(\mathrm{CH}_{2} \mathrm{CH}_{3}\right)(\mathrm{NCMe})_{2}\right]^{+}\left([4]^{+}\right)$was clearly detected in 158 the low temperature region (Figure 2).

The slow rotation of the phenyl groups on the $\mathrm{PhBP}_{3}{ }^{-}$ligand 160 in $[4]^{+}$at $-90{ }^{\circ} \mathrm{C}$ breaks the symmetry plane that relates the 161 two halves of the molecule, so that two resonances were 162 observed for the phosphorus nuclei trans to the acetonitrile 163 
164 ligands $\left(\mathrm{P}^{\mathrm{A}}\right)$. In fact the very likely, regular propeller-like 165 orientation of the $\mathrm{Ph}$ groups results in a chiral structure where 166 the $\mathrm{P}^{\mathrm{A}}$ atoms are diastereotopic. A similar effect, although less 167 pronounced, was observed for complex $[1]^{+}$(Figure 2). 168 However, signals corresponding to the phosphorus nuclei 169 trans to the hydrido and ethyl ligands $\left(\mathrm{P}^{\mathrm{B}}\right.$ and $\mathrm{P}^{\mathrm{M}}$, respectively) 170 remained almost unaltered. They were found to be high field 171 shifted, as generally observed for phosphorus placed trans to 172 ligands with a strong trans influence. ${ }^{31}$ The rest of the 173 resonances for complex $[4]^{+}$agree with the proposed structure 174 (see Supporting Information).

175 According to its formula, the agostic complex $\left[\mathrm{Rh}\left(\mathrm{PhBP}_{3}\right)\right.$ $\left.176\left(\mathrm{CH}_{2} \mathrm{CH}_{2}-\mu-\mathrm{H}\right)(\mathrm{NCMe})\right]^{+}\left([3]^{+}\right.$, Figure 2$)$ should be the 177 major species at low acetonitrile concentration. Moreover, it is 178 the product from the direct protonation of the rhodium(I) 179 complex $\left[\mathrm{Rh}\left(\mathrm{PhBP}_{3}\right)\left(\mathrm{CH}_{2}=\mathrm{CH}_{2}\right)(\mathrm{NCMe})\right]$ (5). At this 180 point, it should be indicated that repeated preparations of $\mathbf{5}$ 181 lead to orange crystalline solids of composition $5 \cdot 2 \mathrm{NCMe}^{25 a}$ 182 Therefore, further treatment of these solids with $\mathrm{HBF}_{4}$ 183 produces similar equilibria to those obtained from the reaction 184 of $[\mathbf{1}]^{+}$with ethylene commented above.

185 Complex $\mathbf{5}$ is quite unstable in solution but stable enough for 186 a fast recrystallization by solution in toluene and precipitation 187 with hexane. This methodology produces a yellow solid, poorly 188 soluble in toluene, which contains less than $1 \mathrm{~mol} \%$ (per mol 189 of 5) of acetonitrile of crystallization ( ${ }^{1} \mathrm{H}$ NMR evidence). 190 Reaction of these solids with $\mathrm{HBF}_{4}$ in dichloromethane gave $191\left[\mathrm{Rh}\left(\mathrm{PhBP}_{3}\right)\left(\mathrm{CH}_{2} \mathrm{CH}_{2}-\mu-\mathrm{H}\right)(\mathrm{NCMe})\right]^{+}\left([3]^{+}\right)$in almost quan192 titative yield (Figure 2, red trace). The reaction was found to be 193 instantaneous, as indicated by a color change from yellow to 194 pale yellow. Attempts to isolate $[3]^{+}$as a solid systematically 195 produced mixtures of unidentified complexes and therefore it 196 was characterized "in situ". Thus, three well-defined resonances 197 were observed in the ${ }^{31} \mathrm{P}\left\{{ }^{1} \mathrm{H}\right\}$ NMR spectrum at $-89.3{ }^{\circ} \mathrm{C}$, 198 (Figure 2, red trace), while the ethyl group produces three 199 signals in a 1:1:3 ratio in the ${ }^{1} \mathrm{H}$ NMR spectrum that 200 correspond to the two diastereotopic methylene protons and 201 the methyl group, respectively (see Supporting Information).

Equilibria between Complexes $[1]^{+},[3]^{+}$, and $[4]^{+}$. 203 Detection of the equilibria between the title complexes was 204 achieved by VT- ${ }^{1} \mathrm{H}$ selective NOE NMR spectra (selnOe); two 205 of them are shown in Figure 3. The equilibrium between $[3]^{+}$ 206 and $[4]^{+}$is clearly evidenced in the selnOe spectrum at -21.6 $207{ }^{\circ} \mathrm{C}$ upon irradiation of the methyl group of the $\beta$-agostic

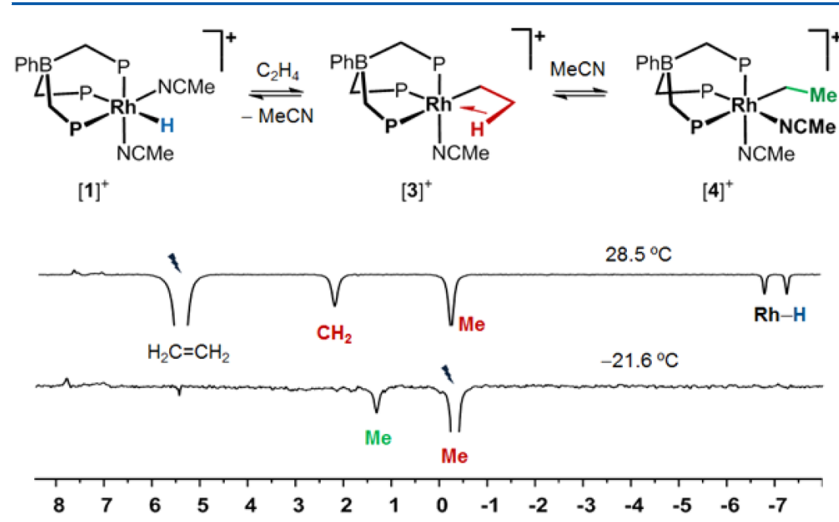

Figure 3. Selective NOE (selnOe) spectra upon irradiation of selected resonances (indicated with a ray) of the reaction mixture from the hydride complex $\left[\mathrm{Rh}\left(\mathrm{PhBP}_{3}\right)(\mathrm{H})(\mathrm{NCMe})_{2}\right]^{+}\left([\mathbf{1}]^{+}\right)$and ethylene in $\mathrm{CD}_{2} \mathrm{Cl}_{2}$. species, which produces an exchange peak with the methyl 208 group in the ethyl complex $[4]^{+}$. No exchange signal was 209 observed for the hydride resonance of $[\mathbf{1}]^{+}$, suggesting that 210 equilibrium involving $[\mathbf{1}]^{+}$is a higher energy process.

211

At $28.5{ }^{\circ} \mathrm{C}$, the participation of $[\mathbf{1}]^{+}$is clearly detected from 212 the exchange peaks observed upon irradiation of the signal 213 corresponding to free ethylene. Notice that the two methylenic 214 protons of the $\beta$-agostic complex $\left(\mathrm{H}^{2 \mathrm{a}}\right.$ and $\left.\mathrm{H}^{2 \mathrm{~b}}\right)$ are chemically 215 equivalent at this temperature. These NMR short-time- 216 consuming experiments allow the different dynamic processes 217 observed by ${ }^{1} \mathrm{H}$ NMR to be organized in a qualitative, but 218 precise, way.

The van't Hoff plot, obtained from the integral data of the 220 VT- ${ }^{1} \mathrm{H}$ NMR spectra, gave the thermodynamic parameters 221 listed in Table 1 (see Supporting Information for details). In $222 \mathrm{t} 1$

Table 1. Experimental Thermodynamic Data ${ }^{a}$ for Reactions Involving Complexes $[1]^{+},[3]^{+}$, and $[4]^{+}$

$\begin{array}{lll}\text { reaction } & {[3]^{+}+\mathrm{NCMe} \leftrightarrows[1]^{+}+\mathrm{C}_{2} \mathrm{H}_{4}(1)} & {[3]^{+}+\mathrm{NCMe} \leftrightarrows[4]^{+}(2)} \\ \Delta H^{\circ} & -2.6 \pm 0.4 & -6.3 \pm 0.2 \\ \Delta S^{\circ} & -5 \pm 1 & -23 \pm 1 \\ \Delta G^{\circ}{ }_{298.15} & -1.1 & 0.4 \\ \Delta G^{\circ}{ }_{198.15} & -1.61 & -1.86 \\ T \text { range } & -30 \text { to } 30{ }^{\circ} \mathrm{C} & -90 \text { to }-30{ }^{\circ} \mathrm{C} \\ { }^{a} \Delta H^{\circ} \text { and } \Delta G^{\circ} \text { in kcal mol }{ }^{-1}, \Delta S^{\circ} \text { in cal mol }{ }^{-1} \mathrm{~K}^{-1} .\end{array}$

both reactions, a negative value of enthalpy was found, which 223 indicates that both reactions are exothermic, with the ethyl 224 complex $[4]^{+}$and the hydride compound $[1]^{+}$being lower in 225 enthalpy than the $\beta$-agostic species $[3]^{+}$.

However, the entropy change is also negative in both cases. 227 For equilibrium 2, the value of $-23 \pm 1 \mathrm{cal} \mathrm{mol} \mathrm{K}{ }^{-1}$ mainly 228 corresponds to coordination of acetonitrile to rhodium, while 229 for the first one, the smaller value of $-5 \pm 1 \mathrm{cal} \mathrm{mol} \mathrm{K}{ }^{-1}$ mainly 230 reflects the difference between acetonitrile versus ethylene (as 231 an ethyl group) coordination. Looking at the reactions in the 232 opposite sense, formation of the $\beta$-agostic complex $[3]^{+}$is 233 endothermic, but in both cases, the entropy change is positive. 234 Therefore, the formation of the $\beta$-agostic complex $[3]^{+}$from 235 $[\mathbf{1}]^{+}$or $[4]^{+}$is an entropy-driven reaction, in which acetonitrile 236 dissociation from both the ethyl and the hydride complexes is 237 the driving force.

238

Data in Table 1 also account for the experimental 239 observation that the addition of acetonitrile to the $\beta$-agostic 240 complex quantitatively produces the hydride complex $[1]^{+} 241$ rather than the expected ethyl complex $[4]^{+}$. Indeed, a value 242 of $\Delta G^{\circ}{ }_{298.15}$ of $-1.5 \mathrm{kcal} \mathrm{mol}^{-1}$ can be estimated for the 243 reaction $[\mathbf{4}]^{+} \leftrightarrows[\mathbf{1}]^{+}+\mathrm{C}_{2} \mathrm{H}_{4}$ from data in Table 1 . 244

DFT Studies on the $\boldsymbol{\beta}$-Agostic Complex [3a] ${ }^{+}$and the 245 Related Ethyl Rotamers [3b] $]^{+}$and $[3 \mathbf{c}]^{+}$. Complex $[3]^{+}$was 246 first examined by a DFT study (b3-lyp, LanL2DZ, and 6- 247 $\left.31 \mathrm{G}^{* *}\right)$ using the full complex $\left[\mathrm{Rh}\left\{\mathrm{PhB}\left(\mathrm{CH}_{2} \mathrm{PPh}_{2}\right)_{3}\right\}\left(\mathrm{C}_{2} \mathrm{H}_{4}-\mu-248\right.\right.$ $\mathrm{H})(\mathrm{NCMe})]\left([3 \mathrm{a}]^{+}\right)$as a model. The $\mathrm{BF}_{4}{ }^{-}$counteranion was 249 not included, since evidence for its noncoordination to 250 rhodium was obtained from dosy experiments. Thus, a value 251 for the diffusion coefficient of $19.04 \mathrm{~m}^{2} \mathrm{~s}^{-1}$ corresponding to a 252 hydrodynamic radius of $2.89 \AA$ was obtained from ${ }^{19} \mathrm{~F}$-dosy 253 NMR spectra of $[3] \mathrm{BF}_{4}$ in $\mathrm{CD}_{2} \mathrm{Cl}_{2}$. These values correspond 254 well with that reported for the $\mathrm{BF}_{4}{ }^{-}$anion in inorganic salts 255 such as $\mathrm{LiBF}_{4}{ }^{32}$

An energy minimum was found for the $\beta$-agostic complex 257 $[3 \mathrm{a}]^{+}$with a $\mathrm{Rh} \cdots \mathrm{H}^{3 \mathrm{a}}$ distance of $2.278 \AA$, which lies in the 258 


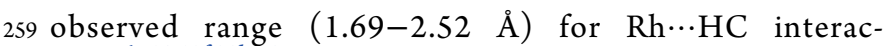
260 tions. $^{6 c, 10,12 f, 23 b, 33}$ Nonetheless, a more precise structure was

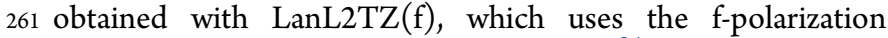
262 functions developed by Frenking's group, ${ }^{34}$ allowing a better 263 representation of the secondary interactions. With this basis set, 264 the $\mathrm{Rh} \cdots \mathrm{H}^{3 \mathrm{a}}$ distance reduces to $2.083 \AA$, a value that matches 265 much better with that expected. Therefore, all the rest of the 266 intermediates and transition states described below (as well as 267 the above commented complexes $[\mathbf{1 a}]^{+}$and $[2 \mathbf{a}]^{+}$) have been 268 calculated at the same level of theory for comparative purposes. 269 The $\beta$-agostic interaction in $[3 \mathrm{a}]^{+}$is also associated with an 270 elongation of the corresponding $\mathrm{C}^{\beta}-\mathrm{H}^{3 \mathrm{a}}$ bond distance $(1.143$ $271 \AA$ ) if compared with the other two $\mathrm{C}^{\beta}-\mathrm{H}^{3 \mathrm{~b} / 3 \mathrm{c}}$ bond distances 272 (Figure 4, left). The carbon-carbon distance in the ethyl group

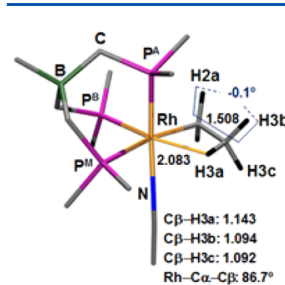

$[3 \mathrm{~b}]^{+}(E=0.6)$

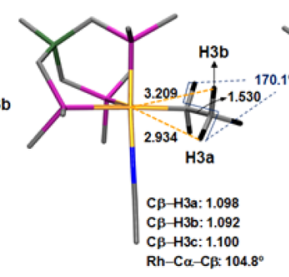

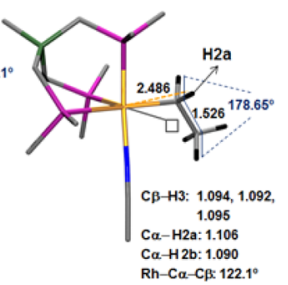

$[3 c]^{+}(E=3.8)$
Figure 4. DFT calculated structures for complexes $[3 \mathbf{a}]^{+},[\mathbf{3 b}]^{+}$, and $[3 \mathrm{c}]^{+}$. Values of energy are given in $\mathrm{kcal} \mathrm{mol}^{-1}$ and $\mathrm{C}-\mathrm{H}$ bond distances in $\AA$. Only $\mathrm{C}^{i \text { iso }}$ of the phenyl groups and protons of the ethyl group are shown for clarity.

273 elongates from 1.443(7) $\AA$ observed in $\left[\mathrm{Rh}\left(\mathrm{PhBP}_{3}\right)\left(\mathrm{CH}_{2}=\right.\right.$ $\left.\left.274 \mathrm{CH}_{2}\right)(\mathrm{NCMe})\right](5)$ to $1.508 \AA$ according to the presence of a 275 single $\mathrm{C}-\mathrm{C}$ bond. Moreover, the coordination polyhedron of 276 the metal is close to the octahedron with $\mathrm{C}^{\alpha}$ trans to $\mathrm{P}^{\mathrm{M}}, \mathrm{N}$ 277 trans to $\mathrm{P}^{\mathrm{A}}$, and the methyl group approaching to the position 278 trans to $\mathrm{P}^{\mathrm{B}}$. Furthermore, the eclipsed conformation of the ethyl 279 group also supports the $\beta$-agostic interaction, since otherwise a 280 staggered conformation should be expected.

281 Two related minima close in energy, $[3 \mathbf{b}]^{+}$and $[3 \mathbf{c}]^{+}$, were 282 also found, and their structures are shown in Figure 4 . Both 283 isomers are better described as nonagostic ethyl complexes, 284 which is remarkable since such type of isomers have been 285 considered high energy species. ${ }^{14 b, 15 b, f}[3 \mathbf{b}]^{+}$and $[3 \mathbf{c}]^{+}$show a 286 staggered conformation for the ethyl group in contrast to the 287 eclipsed conformation found for $[3 \mathbf{a}]^{+}$(Figure 4).

288 In addition, isomer $[3 \mathbf{b}]^{+}$shows very long $\mathrm{Rh} \cdots \mathrm{H}^{3 a / 3 b}$ 289 distances while the $\mathrm{C}^{\beta}-\mathrm{H}^{3 \mathrm{a} / 3 \mathrm{~b} / 3 \mathrm{c}}$ bond distances are almost 290 identical. Concerning isomer $[3 \mathbf{c}]^{+}$, it could be considered as an $291 \alpha$-agostic species, but the $\mathrm{H}^{2 \mathrm{a}}$ proton is far away from the 292 coordination vacancy-represented with a square in Figure 4 293 (right) - leading to a quite long $\mathrm{Rh} \cdots \mathrm{H}^{2 \mathrm{a}}$ distance. A major 294 difference between the ethyl complexes $[3 \mathbf{b}]^{+}$and $[3 \mathbf{c}]^{+}$comes 295 from the orientation of the ethyl group in such a way that the 296 methyl group is placed in the region corresponding to the sixth 297 position of the octahedron in $[3 \mathbf{b}]^{+}$, while it is fully eclipsed to 298 the acetonitrile ligand in $[3 \mathbf{c}]^{+}$. This orientation is associated 299 with an opening of the angle $\mathrm{Rh}-\mathrm{C}^{\alpha}-\mathrm{C}^{\beta}$, in $[3 \mathrm{c}]^{+}$relative to $300[\mathbf{3 b}]^{+}$, and, most probably, it is the origin of the higher energy 301 found for $[3 \mathbf{c}]^{+}$.

302 A comparison between isomers $[3 \mathbf{a}]^{+}$and $[\mathbf{3 b}]^{+}$indicates 303 that the small difference in energy between them represents the 304 balance of cleaving the agostic interaction versus the 305 stabilization provided by the conformational change of the ethyl group from eclipsed to staggered. Since this difference for 306 ethane is about $2.8 \mathrm{kcal} \mathrm{mol}^{-1}$, the $\beta$-agostic interaction in $[3 \mathrm{a}]^{+} 307$ can be estimated as ca. $2.8+0.6=3.5 \mathrm{kcal} \mathrm{mol}^{-1}$. ${ }^{36}$

The three isomers easily interconvert through transition 309 states TS-2 and TS-3 (Figure 5). The gray path relates $[3 \mathbf{a}]^{+} 310 \mathrm{f5}$

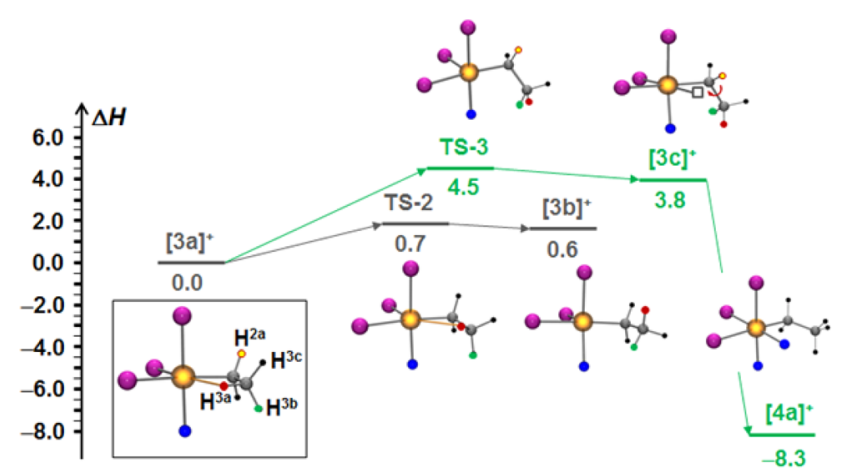

Figure 5. Energy profile for transformations between $[3 \mathbf{a}]^{+},[3 \mathbf{b}]^{+}$, $[3 \mathbf{c}]^{+}$, and the ethyl bis(acetonitrile) complex $[4 \mathbf{a}]^{+}$. Values of $\Delta H$ are given in kcal mol${ }^{-1}$. Only the $\mathrm{P}$ atoms of $\mathrm{PhBP}_{3}^{-}$(purple) and $\mathrm{N}$ atoms of acetonitrile (blue) are shown for clarity.

with $[\mathbf{3 b}]^{+}$, and corresponds to the "in place rotation", 311 responsible for the chemical equivalence of the methylenic 312 protons $\mathrm{H}^{3 \mathrm{a}}, \mathrm{H}^{3 \mathrm{~b}}$, and $\mathrm{H}^{3 \mathrm{c}}$. The process has practically no 313 energy barrier, and accordingly, the three methyl protons are 314 chemically equivalent in the ${ }^{1} \mathrm{H}$ NMR spectrum of $[3]^{+}$at -90315 ${ }^{\circ} \mathrm{C}$.

The path in green connects $[3 \mathbf{a}]^{+}$to $[3 \mathbf{c}]^{+}$and then to the 317 ethyl bis(acetonitrile) complex $[\mathbf{4 a}]^{+}$after acetonitrile coordi- 318 nation to the vacant site in $[3 \mathbf{c}]^{+}$. The enthalpy value for the 319 reaction $[\mathbf{3 a}]^{+}+\mathrm{NCMe} \leftrightarrows[\mathbf{4 a}]^{+}$has been estimated as -8.3320 $\mathrm{kcal} \mathrm{mol}^{-1}$, in good agreement with the experimental value of 321 $-6.3 \mathrm{kcal} \mathrm{mol}^{-1}$ measured experimentally (Table 1 ). 322

Energy Profile for Equilibrium between Complexes 323 $[1 \mathrm{a}]^{+}$and $[3 \mathrm{a}]^{+}$. The reaction of the hydride $\left[\mathrm{Rh}\left(\mathrm{PhBP}_{3}\right)-324\right.$ $\left.(\mathrm{H})(\mathrm{NCMe})_{2}\right]^{+}\left([\mathbf{1}]^{+}\right)$with ethylene leading to $\left[\mathrm{Rh}\left(\mathrm{PhBP}_{3}\right)-325\right.$ $\left.\left(\mathrm{CH}_{2} \mathrm{CH}_{2}-\mu-\mathrm{H}\right)(\mathrm{NCMe})\right]^{+}\left([3]^{+}\right)$would require the three 326 elementary steps depicted in Figure 6: (i) acetonitrile $327 \mathrm{fo}$ dissociation, (ii) ethylene coordination, and (iii) ethylene 328 insertion into the $\mathrm{Rh}-\mathrm{H}$ bond. The first step gives the square- 329 pyramidal complex $\left[\mathrm{Rh}\left(\mathrm{PhBP}_{3}\right)(\mathrm{H})(\mathrm{NCMe})\right]^{+}\left([\mathbf{2 a}]^{+}\right)$as 330 commented above. Ethylene coordination renders the hydride 331 ethylene complex $\left[\mathrm{Rh}\left(\mathrm{PhBP}_{3}\right)\left(\mathrm{C}_{2} \mathrm{H}_{4}\right)(\mathrm{H})(\mathrm{NCMe})\right]^{+}\left([\mathbf{6 a}]^{+}\right) 332$ and takes place through a transition state TS-4 whose enthalpy 333 is similar to that of the intermediate $[\mathbf{2 a}]^{+}$. Ethylene insertion in 334 $[3 \mathrm{a}]^{+}$occurs with a low energy barrier $\left(2.5 \mathrm{kcal} \mathrm{mol}^{-1}\right)$ through 335 the transition state TS-5, which was also found to possess an 336 agostic interaction (see Supporting Information).

337

From a thermodynamic point of view, the calculated 338 enthalpy for the equilibrium $[\mathbf{3 a}]^{+}+\mathrm{NCMe} \leftrightarrows[\mathbf{1 a}]^{+}+\mathrm{C}_{2} \mathrm{H}_{4} 339$ was estimated as $-4.7 \mathrm{kcal} \mathrm{mol}^{-1}$, in good agreement with that 340 experimentally measured $\left(-2.6 \mathrm{kcal} \mathrm{mol}^{-1}\right.$, Table 1$)$. 341

Under a kinetic perspective, the activation barrier for the 342 transformation of the hydride complex $[\mathbf{1 a}]^{+}$into the $\beta$-agostic 343 species $[3 \mathrm{a}]^{+}$is mainly determined by the acetonitrile extrusion 344 $\left(\Delta H^{\ddagger}=16.3 \pm 1.0 \mathrm{kcal} \mathrm{mol}^{-1}\right.$ by NMR and ca. $17.8 \mathrm{kcal} \mathrm{mol}^{-1} 345$ by DFT) or the ethylene coordination through TS-4 $\left(\Delta H^{\ddagger}=346\right.$ 18.3 by DFT), which prevents direct measurements of the 347 barrier for the ethylene insertion by NMR. 


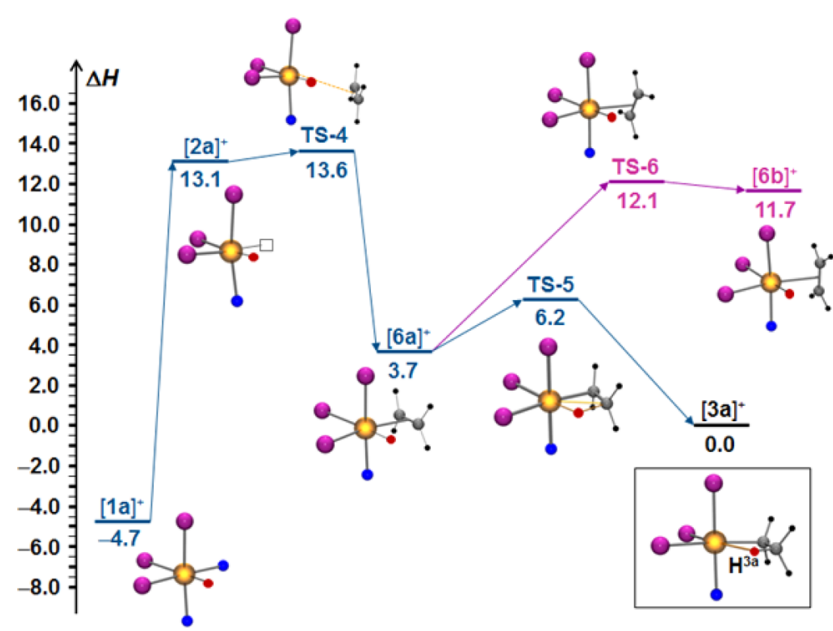

Figure 6. Energy profile for the reaction of $\left[\mathrm{Rh}\left(\mathrm{PhBP}_{3}\right)(\mathrm{H})\right.$ $\left.(\mathrm{NCMe})_{2}\right]^{+}\left([\mathbf{1 a}]^{+}\right)$with ethylene to give the $\beta$-agostic complex $\left[\mathrm{Rh}\left(\mathrm{PhBP}_{3}\right)\left(\mathrm{CH}_{2} \mathrm{CH}_{2}-\mu-\mathrm{H}\right)(\mathrm{NCMe})\right]^{+}\left([3 \mathrm{a}]^{+}\right)$. Values of $\Delta H$ are given in kcal mol${ }^{-1}$. Only the $\mathrm{P}$ atoms (purple) of $\mathrm{PhBP}_{3}{ }^{-}$and $\mathrm{N}$ atoms (blue) of acetonitrile are shown for clarity.

349 Figure 6 also includes the isomer of the hydrido-ethylene 350 complex $[6 \mathbf{b}]^{+}$, in which the ethylene ligand is rotated $90^{\circ}$ and 351 lies higher in enthalpy by $8.0 \mathrm{kcal} \mathrm{mol}^{-1}$ relative to $[6 \mathrm{a}]^{+}$.

352 Ethylene rotation (path in purple) takes place through the 353 accessible transition state TS-6 in which ethylene is twisted in 354 around $23^{\circ}$.

355 Fluxional Behavior of Complex $[3]^{+}$in Solution. The 356 dynamic processes undergone by the $\beta$-agostic complex $[3]^{+}$ 357 were examined by $\mathrm{VT}-{ }^{31} \mathrm{P}\left\{{ }^{1} \mathrm{H}\right\}$ NMR. Experimental line shapes 358 were compared to calculated ones by using the gNMR 359 simulation program, ${ }^{37}$ and a set of observed and simulated 360 spectra is shown in Figure 7. Two different rate constants were 361 required to reproduce the experimental spectra. The first one $362\left(k_{\mathrm{P} 1}\right)$ corresponds to the process that equilibrates $\mathrm{P}^{\mathrm{A}}$ with $\mathrm{P}^{\mathrm{B}}$, 363 while the second one $\left(k_{\mathrm{P} 2}\right)$ is responsible of the equilibration of $364 \mathrm{P}^{\mathrm{A}} / \mathrm{P}^{\mathrm{B}}$ with $\mathrm{P}^{\mathrm{M}}$.

365 Fitting the data into the corresponding Eyring plots gives the 366 activation parameters: $\Delta H_{1}^{\ddagger}=11.4 \pm 0.4 \mathrm{kcal} \mathrm{mol}^{-1}, \Delta S_{1}^{\ddagger}=$

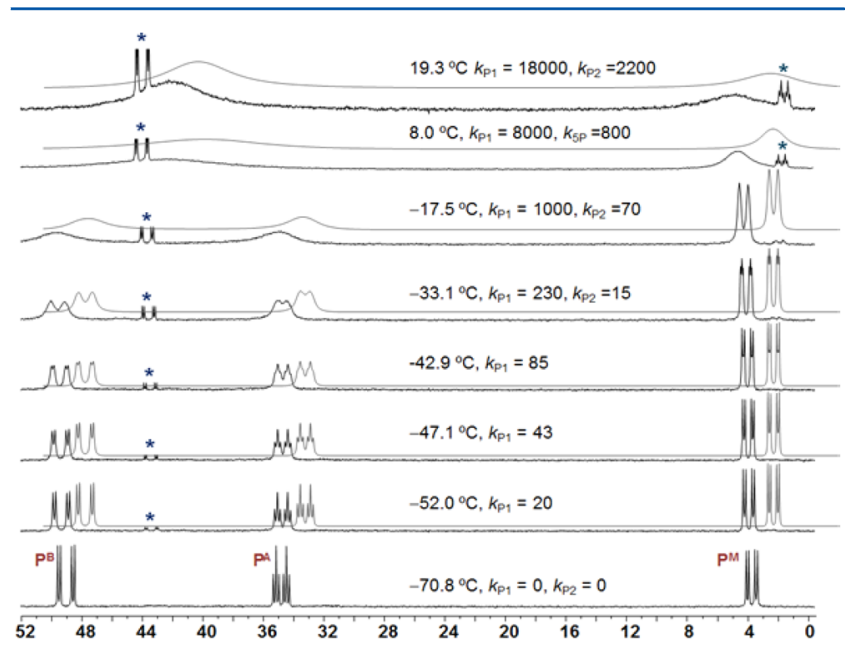

Figure 7. Experimental and calculated (traces in gray) $\mathrm{VT}_{-}{ }^{31} \mathrm{P}\left\{{ }^{1} \mathrm{H}\right\}$ NMR spectra of $\left[\mathrm{Rh}\left(\mathrm{PhBP}_{3}\right)\left(\mathrm{CH}_{2} \mathrm{CH}_{2}-\mu-\mathrm{H}\right)(\mathrm{NCMe})\right]^{+}\left([3]^{+}\right)$in $\mathrm{CD}_{2} \mathrm{Cl}_{2}$. The asterisk denotes signals corresponding to the hydride complex $[1]^{+}$.
$-0 \pm 1 \mathrm{cal} \mathrm{mol}^{-1} \mathrm{~K}^{-1}$ for the first one and $\Delta H_{2}^{\ddagger}=12.8 \pm 0.5367$ $\mathrm{kcal} \mathrm{mol}^{-1}, \Delta S_{2}^{\ddagger}=-0.5 \pm 1 \mathrm{cal} \mathrm{mol}^{-1} \mathrm{~K}^{-1}$ for the second one 368 (see Supporting Information for details).

The simplest explanation for both fluxional processes is 370 illustrated in Scheme 1. Starting from isomer $[3 \mathbf{c}]^{+}$, a shift of $371 \mathrm{sl}$

Scheme 1. Dynamic Processes Undergone by Complex [3] ${ }^{+}$ in Solution Detected by ${ }^{31} \mathrm{P}\left\{{ }^{1} \mathrm{H}\right\}$ NMR

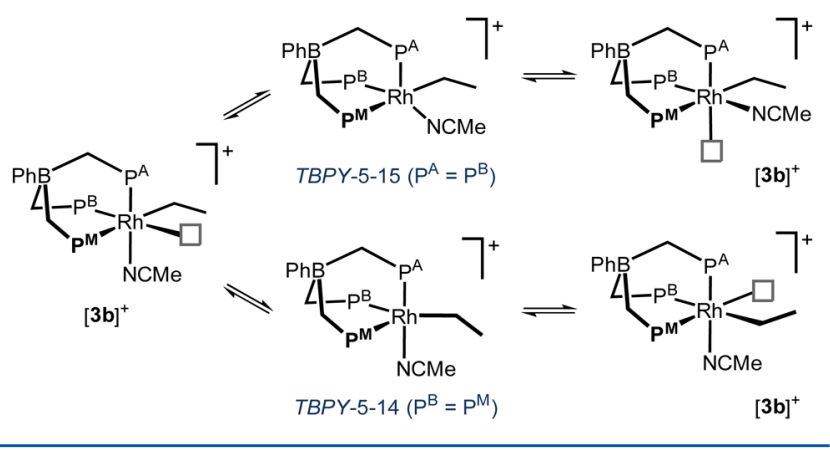

acetonitrile to the coordination vacancy equilibrates $\mathrm{P}^{\mathrm{A}}$ with $\mathrm{P}^{\mathrm{B}}, 372$ while moving the ethyl group to the coordination vacancy 373 equilibrates $\mathrm{P}^{\mathrm{B}}$ with $\mathrm{P}^{\mathrm{M}}$. Both processes would take place 374 through the corresponding TBPY geometries, so that the small 375 difference in the enthalpy measured experimentally would 376 represent the difference between the geometries TBPY-5-15 377 and TBPY-5-14.

378

Attempts to find these TBPY geometries as transition states 379 by DFT failed, but it was possible to find the related TBPY-5-14 380 starting from the simplest species containing a hydride ligand 381 instead of the ethyl group $\left[\mathrm{Rh}\left(\mathrm{PhBP}_{3}\right)(\mathrm{H})(\mathrm{NCMe})\right]^{+}\left([\mathbf{2 a}]^{+}\right) 382$ (see Supporting Information). Thus, the difference in enthalpy 383 between SPY-[2a ${ }^{+}$and TBPY-5-14-[2a $]^{+}$was found to be 11.0384 $\mathrm{kcal} \mathrm{mol}^{-1}$, which lies in the range of the measured values for 385 the acetonitrile shift or ethyl shift in the $\beta$-agostic complex [3] ${ }^{+} .386$ Notice that any process shown in Scheme 1 also equilibrates 387 $\mathrm{H}^{2 \mathrm{a}} / \mathrm{H}^{2 \mathrm{~b}}$ (the methylenic protons of the ethyl group), for which 388 the energy barrier has been rarely measured experimentally. 389

An intriguing feature of the $\mathrm{VT}-{ }^{31} \mathrm{P}\left\{{ }^{1} \mathrm{H}\right\}$ spectra (Figure 7) is 390 the "appearance" of the hydride complex $[\mathbf{1}]^{+}$, whose signals 391 increase in intensity on raising temperature, and certainly, this 392 is not a problem of solubility of $[\mathbf{1}]^{+}$in $\mathrm{CD}_{2} \mathrm{Cl}_{2}$. Therefore, the 393 most reasonable proposal to explain this observation is to 394 consider the existence of an additional source of acetonitrile in 395 solution. Consequently, dissociation of acetonitrile from both 396 the $\beta$-agostic species and the hydride olefin intermediate 397 $\left[\mathrm{Rh}\left(\mathrm{PhBP}_{3}\right)(\mathrm{H})\left(\mathrm{C}_{2} \mathrm{H}_{4}\right)(\mathrm{NCMe})\right]^{+}\left([\mathbf{6 a}]^{+}\right)$have also been 398 analyzed by DFT studies.

399

DFT Studies on the $\beta$-Agostic $\left[\mathrm{Rh}\left(\mathrm{PhBP}_{3}\right)\left(\mathrm{CH}_{2} \mathrm{CH}_{2}-\mu-400\right.\right.$ $\mathrm{H})]^{+}\left([8 \mathrm{a}]^{+}\right)$and Related Complexes. Figure 8 shows the $401 \mathrm{f} 8$ energy profile corresponding to the extrusion of acetonitrile 402 from $[\mathbf{6 a}]^{+}$and $[\mathbf{3 a}]^{+}$; both processes converge into the $\beta$ - 403 agostic species $\left[\mathrm{Rh}\left(\mathrm{PhBP}_{3}\right)\left(\mathrm{CH}_{2} \mathrm{CH}_{2}-\mu-\mathrm{H}\right)\right]^{+}\left([\mathbf{8 a}]^{+}\right)$. Starting 404 from $[6]^{+}$, the dissociation of acetonitrile produces the square- 405 pyramidal complex $\left[\mathrm{Rh}\left(\mathrm{PhBP}_{3}\right)(\mathrm{H})\left(\mathrm{C}_{2} \mathrm{H}_{4}\right)\right]^{+}\left([7 \mathrm{a}]^{+}\right)$, and the 406 insertion of ethylene into the $\mathrm{Rh}-\mathrm{H}$ bond to give $[\mathrm{Rh}-407$ $\left.\left(\mathrm{PhBP}_{3}\right)\left(\mathrm{CH}_{2} \mathrm{CH}_{2}-\mu-\mathrm{H}\right)\right]^{+}\left([\mathbf{8 a}]^{+}\right)$occurs through the tran- 408 sition state TS-7. Nonetheless, the direct dissociation of 409 acetonitrile from $\left[\mathrm{Rh}\left(\mathrm{PhBP}_{3}\right)\left(\mathrm{CH}_{2} \mathrm{CH}_{2}-\mu \text {-H }\right)(\mathrm{NCMe})\right]^{+} 410$ $\left([3 \mathrm{a}]^{+}\right)$produces an alternative path lower in enthalpy. 411

Complex $\left[\mathrm{Rh}\left(\mathrm{PhBP}_{3}\right)\left(\mathrm{CH}_{2} \mathrm{CH}_{2}-\mu-\mathrm{H}\right)\right]^{+}\left([\mathbf{8 a}]^{+}\right)$was found 412 to be $16.6 \mathrm{kcal} \mathrm{mol}^{-1}$ (in enthalpy) higher than $\left[\mathrm{Rh}\left(\mathrm{PhBP}_{3}\right)-413\right.$ 


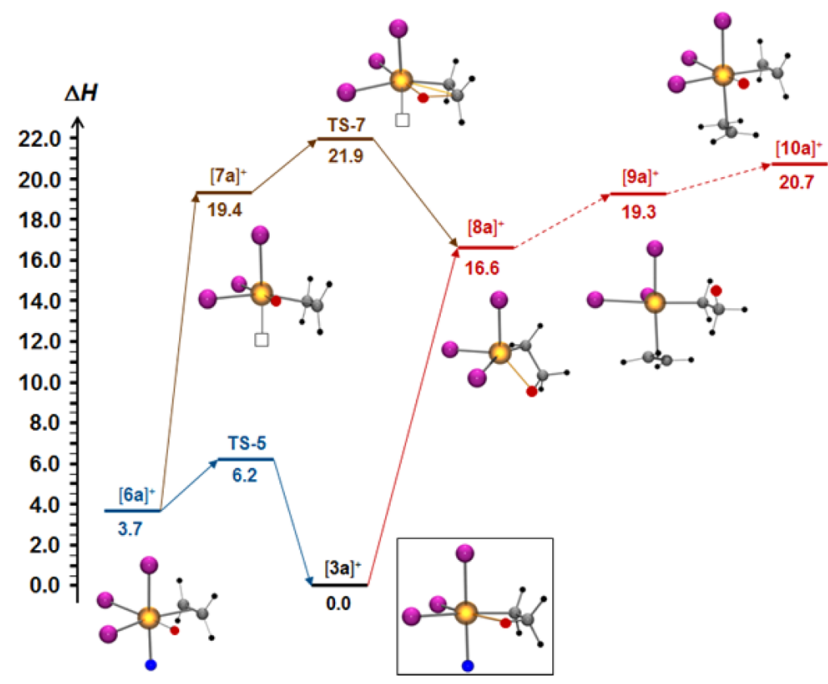

Figure 8. Energy profile for the extrusion of acetonitrile from $[6 \mathbf{6 a}]^{+}$ and $[3 \mathrm{a}]^{+}$. Values of $\Delta H$ are given in $\mathrm{kcal} \mathrm{mol}^{-1}$. Only the $\mathrm{P}$ atoms (purple) of $\mathrm{PhBP}_{3}{ }^{-}$and $\mathrm{N}$ atoms (blue) of acetonitrile are shown for clarity.

$\left.414\left(\mathrm{CH}_{2} \mathrm{CH}_{2}-\mu-\mathrm{H}\right)(\mathrm{NCMe})\right]^{+}\left([3 \mathbf{a}]^{+}\right)$, a value slightly smaller 415 than that found for the extrusion of acetonitrile from the 416 hydride complex $\left[\mathrm{Rh}\left(\mathrm{PhBP}_{3}\right)(\mathrm{H})(\mathrm{NCMe})_{2}\right]^{+}\left([\mathbf{1 a}]^{+}\right)$to give $417\left[\mathrm{Rh}\left(\mathrm{PhBP}_{3}\right)(\mathrm{H})(\mathrm{NCMe})\right]^{+}\left([2 \mathrm{a}]^{+}, 17.8 \mathrm{kcal} \mathrm{mol}^{-1}\right)$. Since the 418 entropy change associated with the dissociation of acetonitrile 419 is expected to be similar for both reactions (from $[\mathbf{1 a}]^{+}$and 420 from $[3 \mathbf{a}]^{+}$), we can conclude than complex $[8 \mathbf{a}]^{+}$is indeed 421 present in solution. Moreover, the formation of $[\mathbf{8 a}]^{+}$is the 422 origin of the additional source of acetonitrile in the reaction 423 medium.

424 Agostic complexes with low electron counts are very unusual, 425 although complexes $\left[\mathrm{Rh}(\mathrm{POCOP})\left(\mathrm{CH}_{2} \mathrm{CH}_{2}-\mu-\mathrm{H}\right)\right]^{+}(\mathrm{POCOP}$ $426=2,6$-bis (di-tert-butylphosphinito)benzene) ${ }^{14 \mathrm{~b}}\left[\mathrm{Rh}\left(\mathrm{C}_{5} \mathrm{Me}_{5}\right)\right.$ $\left.427\left(\mathrm{CH}_{2} \mathrm{CH}_{2}-\mu-\mathrm{H}\right)\right]^{+},{ }_{13}$ and $\left[\mathrm{Rh}\left(\mathrm{P}^{i} \mathrm{Pr}_{3}\right)_{2}\left(\mathrm{CH}_{2} \mathrm{CH}_{2}-\mu-\mathrm{H}\right)\right]^{+},{ }^{21}$ 428 have been studied by DFT in rhodium chemistry.

429 From a thermodynamic point of view, a value of $\Delta G^{\circ}{ }_{298}=$ $430-3.9 \mathrm{kcal} \mathrm{mol}^{-1}$ has been calculated for the reaction shown in 431 Scheme 2, which accounts for the experimental observations 432 just commented.

Scheme 2. Transformation of $\beta$-Agostic Complex $[3 \mathrm{a}]^{+}$into Complexes $[8 \mathrm{a}]^{+}$and $[1 \mathrm{a}]^{+}$

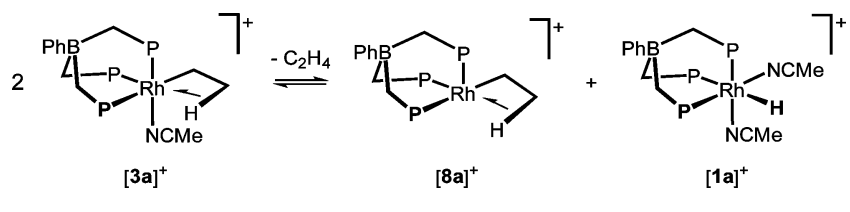

433 For comparative purposes, the ethyl complex $\left[\mathrm{Rh}\left(\mathrm{PhBP}_{3}\right)\right.$ $\left.434\left(\mathrm{C}_{2} \mathrm{H}_{4}\right)\left(\mathrm{CH}_{2} \mathrm{CH}_{3}\right)\right]^{+}\left([\mathbf{9 a}]^{+}\right)$and the hydride bis(ethylene) 435 counterpart $\left[\mathrm{Rh}\left(\mathrm{PhBP}_{3}\right)\left(\mathrm{C}_{2} \mathrm{H}_{4}\right)_{2}(\mathrm{H})\right]^{+}\left([\mathbf{1 0 a}]^{+}\right)$have also 436 been calculated at the same level of theory. For the addition 437 of a second molecule of ethylene to $[\mathbf{8 a}]^{+}$(Figure 8 ) the 438 enthalpy changes are small but the entropy change is strong 439 leading thus to large and positive values for $\Delta G^{\circ}{ }_{298}$. In good 440 agreement, neither $[\mathbf{9 a}]^{+}$nor $[\mathbf{1 0 a}]^{+}$was observed in solution.

441 Figure 9 displays selected structural parameters for 442 complexes $[\mathbf{8 a}]^{+}$and $[\mathbf{9 a}]^{+}$enlightening their different nature. 443 While $[\mathbf{8 a}]^{+}$is clearly a $\beta$-agostic compound, the related $[\mathbf{9 a}]^{+}$

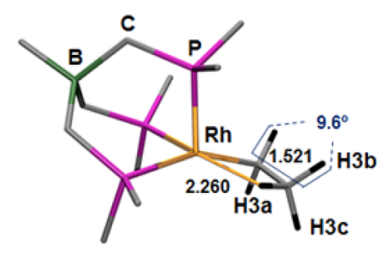

C $\beta-$ H3a: 1.128

C $\beta-\mathrm{H} 3 \mathrm{~b}: 1.093$

$\mathrm{C} \beta-\mathrm{H} 3 \mathrm{c}: 1.095$

$\mathrm{Rh}-\mathrm{C} \alpha-\mathrm{C} \beta: 90.9^{\circ}$

$[8 \mathrm{a}]^{+}$

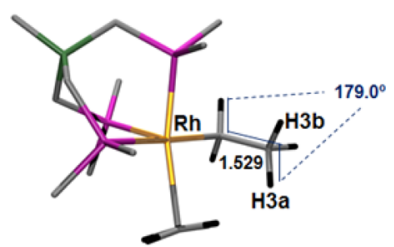
C $\beta-\mathrm{H} 3 \mathrm{~b}: 1.094$

Rh H3a: 3.131 , Rh
C $\beta-\mathrm{H} 3 \mathrm{a}: 1.096$

$\mathrm{Rh}-\mathrm{C} \alpha-\mathrm{C} \beta: 106.9^{\circ}$

Figure 9. DFT calculated structures for complexes $[8 \mathbf{8}]^{+}$and $[9 \mathbf{a}]^{+}$. Distances are given in $\AA$. Only $\mathrm{C}^{i p s o}$ of the phenyl groups and protons of the ethyl group are shown for clarity.

is better described as a terminal nonagostic ethyl complex 444 according to the preceding comments for complexes $[3 \mathbf{a}]^{+}, 445$ $[3 \mathbf{b}]^{+}$, and $[3 \mathbf{c}]^{+}$(Figure 4$)$.

Further Comments on $\boldsymbol{\beta}$-Agostic Rhodium Species. 447 The study reported here provides a unique opportunity to 448 analyze the subtle influence of electronic and steric factors on 449 the strength of the $\beta$-agostic interaction and on the driving 450 force that favors (or not) the transfer of the hydrogen to the 451 metal. As nicely depicted in Table 2 , the strength of the $\beta-452$ t2

Table 2. Selected Parameters for Complexes Shown and $\Delta H^{\circ}$ for the $\beta$-Hydride Elimination Reaction to the Corresponding Hydrido-Ethylene Compound ${ }^{a}$

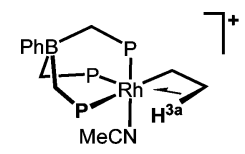

$[3 a]^{+}$

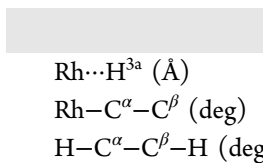

$\Delta H^{\circ}$

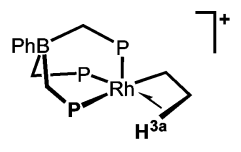

$[8]^{+}$

$[3 \mathrm{a}]^{+}$

2.084

86.74

0.09

$+3.7$

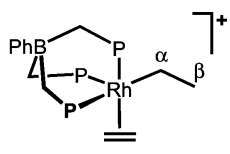

$[9 \mathrm{a}]^{+}$

$[9 a]^{+}$

3.131

106.87

176.64

$+1.4$
${ }^{a}$ Values of $\Delta H^{\circ}$ are given in $\mathrm{kcal} \mathrm{mol}^{-1}$.

agostic interaction, evidenced by shorter $\mathrm{Rh} \cdots \mathrm{H}^{3 \mathrm{a}}$ distances, 453 more acute $\mathrm{Rh}-\mathrm{C}^{\alpha}-\mathrm{C}^{\beta}$ angles, and smaller torsion angles for 454 the protons of the ethyl groups, decreases on going from $[3 \mathbf{a}]^{+} 455$ to $[\mathbf{9 a}]^{+}$, complex $[\mathbf{9 a}]^{+}$being a nonagostic species, but $[\mathbf{8 a}]^{+} 456$ and $[3 \mathbf{a}]^{+}$being clearly $\beta$-agostic compounds.

Of particular relevance is the highly unsaturated complex 458 $[\mathbf{8 a}]^{+}$, which lies between $[\mathbf{3 a}]^{+}$and $[\mathbf{9 a}]^{+}$(despite containing 459 the most electrophilic rhodium center) since it is universally 460 accepted that shorter $\mathrm{M} \cdots \mathrm{H}^{3 \mathrm{a}}$ bond distances (associated with 461 stronger interactions) come from more electrophilic metal 462 centers. Moreover, addition of a ligand to $[\mathbf{8 a}]^{+}$can either fully 463 destroy the $\beta$-agostic interaction or reinforce it, as exemplified 464 by complexes $[9 \mathbf{a}]^{+}$and $[3 \mathbf{a}]^{+}$, respectively. In any case, the 465 beneficial role of the acetonitrile ligand on the stabilization of 466 the $\beta$-agostic interaction is remarkable

467

Values of enthalpy relative to their corresponding hydrido- 468 ethylene counterparts follow a similar trend in such a way that 469 the three ethyl complexes in Table 2 are more stable than the 470 corresponding hydride-ethylene counterparts. This constitutes 471 a quite unusual situation in rhodium chemistry, ${ }^{38}$ since the 472 general trend is just the opposite (as expected for second row 473 transition metals). Since other factors such as trans or solvent 474 
475 effects can be excluded, the steric pressure exerted by the 476 phenyl groups on the $\mathrm{PhBP}_{3}{ }^{-}$ligand should be the key factor 477 that favors the inserted products versus the hydrido-ethylene 478 derivatives, since the former are expected to be less constrained 479 structures than the latter.

480 A third aspect considered concerns the energy barriers for 481 two closely related processes: the "in place rotation" $\left(\mathrm{E}^{\mathrm{i}}\right)$ and 482 the $\beta$-hydride elimination reaction $\left(\mathrm{E}^{\beta}\right)$. As schematically 483 depicted in Scheme 3, the "in place rotation" requires the

Scheme 3. Schematic Representation of the Transition States for the Processes ${ }^{a}$
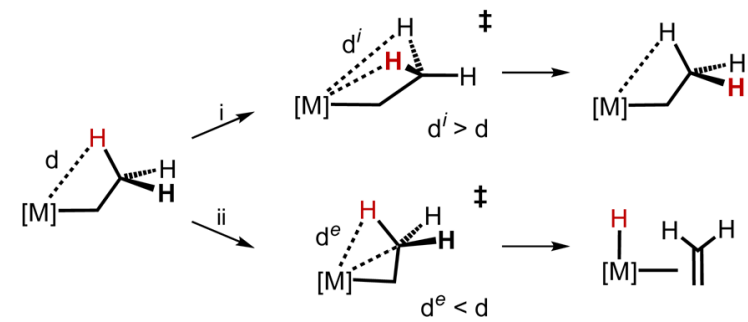

${ }^{a}(\mathrm{i})$ "In place rotation" and (ii) $\beta$-hydride elimination.

484 cleavage of the $\beta$-agostic interaction through a transition state 485 in which the $\mathrm{M} \cdots \mathrm{H}$ distance elongates $\left(d^{\mathrm{i}}>d\right)$. On the 486 contrary, the transition state for the $\beta$-hydride elimination is 487 associated with a shortening of such distance $\left(d^{\mathrm{e}}<d\right)$. It can 488 thus be expected that stronger $\beta$-agostic interactions would 489 require higher energy barriers for the "in place rotation", but 490 lower ones for the $\beta$-hydrido elimination reaction. Indeed, the 491 stronger a $\beta$-agostic interaction is, the closer the structure is to 492 the corresponding transition state for the $\beta$-elimination. 493 Accordingly, the data available from DFT calculations for the 494 rhodium complexes fit nicely under this perspective (see Table $4953)$.

496 Finally, other olefins such as styrene also insert into the $\mathrm{Rh}-$ $497 \mathrm{H}$ bond of complex $[1]^{+}$, although the expected complex $498\left[\mathrm{Rh}\left(\mathrm{PhBP}_{3}\right)\left(\mathrm{CHPhCH}_{2}-\mu-\mathrm{H}\right)(\mathrm{NCMe})\right]^{+}\left([\mathbf{1 1}]^{+}\right)$could not be 499 observed by NMR. Nonetheless, it was detected by exchange 500 spectroscopy experiments. Thus, irradiation of the hydride 501 signal of complex $\left[\mathrm{Rh}\left(\mathrm{PhBP}_{3}\right)(\mathrm{H})(\mathrm{NCMe})_{2}\right]^{+}\left([\mathbf{1}]^{+}\right)$in the 502 presence of styrene revealed the exchange with the signals 503 corresponding to the olefinic protons of styrene (Figure 10, 504 right).

505 Structural parameters calculated by DFT for $[11 \mathrm{a}]^{+}$fit well 506 with those expected for a $\beta$-agostic complex (Figure 10, left), in 507 which the electron withdrawing character of the phenyl group is
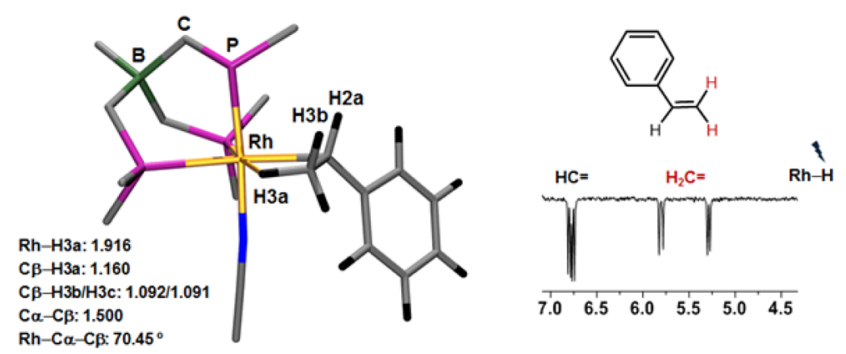

$\mathrm{H} 3 \mathrm{~b}-\mathrm{C} \beta-\mathrm{C} \alpha-\mathrm{H} 2 \mathrm{~b}: 10.83^{\circ}$

Figure 10. DFT-calculated structure for $[11 \mathrm{a}]^{+}$along with selected structural parameters (left) and ${ }^{1} \mathrm{H}$ selnOe NMR spectrum of a solution of $[\mathbf{1}]^{+}$in the presence of 10 molar equiv of styrene upon irradiation of the signal corresponding to the hydrido ligand in $[\mathbf{1}]^{+}$ (right).

reflected in a slightly short $\mathrm{Rh} \cdots \mathrm{H}^{3 \mathrm{a}}$ distance of $1.916 \AA$ when 508 compared to that observed in the ethyl analogue $[3 \mathbf{a}]^{+} .509$ Accordingly, the energy barrier for the "in place rotation" takes 510 place through a transition state similar to complex $[3 \mathbf{b}]^{+}$and it 511 is associated with a $\Delta G^{\ddagger}{ }_{298}$ value of $1.8 \mathrm{kcal} \mathrm{mol}^{-1}$ (see 512 Supporting Information), indicating that interaction of the 513 proton with rhodium is slightly stronger than that observed in 514 the ethyl derivative $[3 \mathbf{a}]^{+}$.

\section{SUMMARY AND CONCLUSIONS}

516

In this paper, we have combined NMR spectroscopy and 517 computational (DFT) studies to gain information about the 518 stability, dynamics, and behavior in solution of $\beta$-agostic/ethyl 519 species in complexes bearing the tripodal ligand $\mathrm{PhBP}_{3}{ }^{-}$. Two 520 of them, $\left[\mathrm{Rh}\left(\mathrm{PhBP}_{3}\right)\left(\mathrm{CH}_{2} \mathrm{CH}_{2}-\mu-\mathrm{H}\right)(\mathrm{NCMe})\right]^{+}\left([3 \mathrm{a}]^{+}\right)$and 521 the highly unsaturated species $\left[\mathrm{Rh}\left(\mathrm{PhBP}_{3}\right)\left(\mathrm{CH}_{2} \mathrm{CH}_{2}-\mu-\mathrm{H}\right)\right]^{+} 522$ $\left([\mathbf{8 a}]^{+}\right)$, were found to be real $\beta$-agostic complexes, while the 523 related rotamers, $[3 \mathbf{b}]^{+}$and $[3 \mathbf{c}]^{+}$, as well as $\left[\mathrm{Rh}\left(\mathrm{PhBP}_{3}\right)-524\right.$ $\left.\left(\mathrm{C}_{2} \mathrm{H}_{4}\right)\left(\mathrm{CH}_{2} \mathrm{CH}_{3}\right)\right]^{+}\left([9 \mathrm{a}]^{+}\right)$are better described as nonagostic 525 ethyl complexes. This result is remarkable, since such type of 526 compounds have been considered as high energy species. 527 Moreover, a comparison of complexes $[3 \mathbf{a}]^{+}$and $[9 \mathbf{9}]^{+}$revealed 528 the key role of the fifth ligand in stabilizing (acetonitrile) or 529 destroying (ethylene) the $\beta$-agostic interaction in these ethyl 530 derivatives. Furthermore, starting from $\left[\mathrm{Rh}\left(\mathrm{PhBP}_{3}\right)-531\right.$ $\left.\left(\mathrm{CH}_{2} \mathrm{CH}_{3}\right)(\mathrm{NCMe})_{2}\right]^{+}\left([\mathbf{4 a}]^{+}\right)$, dissociation of acetonitrile 532 was found to be the driving force to $\left[\mathrm{Rh}\left(\mathrm{PhBP}_{3}\right)\left(\mathrm{CH}_{2} \mathrm{CH}_{2}-533\right.\right.$ $\mu-\mathrm{H})(\mathrm{NCMe})]^{+}\left([3 \mathrm{a}]^{+}\right)$; a similar behavior was observed for 534 $[3 \mathrm{a}]^{+}$, which transforms into $\left[\mathrm{Rh}\left(\mathrm{PhBP}_{3}\right)\left(\mathrm{CH}_{2} \mathrm{CH}_{2}-\mu-\mathrm{H}\right)\right]^{+}{ }_{535}$ $\left([\mathbf{8 a}]^{+}\right)$at higher temperature. Accordingly, NMR-measured 536

Table 3. DFT-Calculated $R h-H$ and $R h \cdots H^{3 a}$ Bond Distances $(\AA)$ in Complexes $\left[R h\left(L_{3}\right)(L)(H)\left(H_{2} C=C H_{2}\right)\right]^{+}$and $\left[\mathrm{Rh}\left(\mathrm{L}_{3}\right)(\mathrm{L})\left(\mathrm{CH}_{2} \mathrm{CH}_{3}\right)\right]^{+}$, Respectively, and $\Delta G^{\ddagger}{ }_{298}$ for the Processes "In Place Rotation" $\left(\mathrm{E}^{\mathrm{i}}\right)$ and $\beta$-Elimination Reactions $\left(\mathrm{E}^{\beta}\right)$ $\left(\mathrm{kcal} \mathrm{mol}^{-1}\right)$

\begin{tabular}{|c|c|c|c|c|c|c|c|}
\hline $\mathrm{L}_{3}$ & $\mathrm{~L}$ & $\mathrm{Rh} \cdots \mathrm{H}^{3 \mathrm{a}}$ & $\mathrm{TS}^{a}$ & $\mathrm{Rh}-\mathrm{H}$ & $\mathrm{E}^{\mathrm{i}}$ & $E^{\beta}$ & ref \\
\hline $\mathrm{C}_{5} \mathrm{H}_{5}$ & $\mathrm{P}(\mathrm{OMe})_{3}$ & 1.771 & 1.624 & 1.567 & 10.7 & 0 & $15 b$ \\
\hline $\mathrm{C}_{5} \mathrm{H}_{5}$ & $\mathrm{PMe}_{3}$ & 1.773 & 1.628 & 1.564 & 9.5 & 0 & $15 b$ \\
\hline $\mathrm{C}_{5} \mathrm{H}_{5}$ & $\mathrm{C}_{2} \mathrm{H}_{4}$ & 1.790 & 1.594 & 1.562 & & & $15 \mathrm{c}$ \\
\hline $\mathrm{C}_{5} \mathrm{Me}_{5}$ & $\mathrm{P}(\mathrm{OMe})_{3}$ & 1.818 & 1.629 & 1.466 & 6.7 & 1.6 & $15 \mathrm{~b}$ \\
\hline $\mathrm{C}_{5} \mathrm{Me}_{5}$ & $\mathrm{PMe}_{3}$ & 1.823 & 1.632 & 1.573 & 6.0 & 0.2 & $15 \mathrm{~b}$ \\
\hline $\mathrm{C}_{5} \mathrm{Me}_{5}$ & $\mathrm{C}_{2} \mathrm{H}_{4}$ & 1.827 & 1.599 & 1.568 & & & $15 c$ \\
\hline $\mathrm{PhBP}_{3}$ & $\mathrm{NCMe}$ & 2.083 & 1.621 & 1.561 & 0.44 & 7.35 & $b$ \\
\hline $\mathrm{PhBP}_{3}$ & & 2.260 & 1.632 & 1.572 & 0 & 6.55 & $b$ \\
\hline
\end{tabular}

${ }^{a} \mathrm{Rh} \cdots \mathrm{H}$ distance in the transition state connecting both species. ${ }^{b}$ This work. 
537 equilibrium constants for both equilibria indicate that they are 538 entropy-driven reactions.

539 Notably, the three related hydride complexes $\left[\mathrm{Rh}\left(\mathrm{PhBP}_{3}\right)\right.$ $\left.540\left(\mathrm{C}_{2} \mathrm{H}_{4}\right)(\mathrm{H})(\mathrm{NCMe})\right]^{+}\left([\mathbf{6 a}]^{+}\right), \quad\left[\mathrm{Rh}\left(\mathrm{PhBP}_{3}\right)\left(\mathrm{C}_{2} \mathrm{H}_{4}\right)(\mathrm{H})\right]^{+}$ $541\left([7 \mathbf{a}]^{+}\right)$, and $\left[\mathrm{Rh}\left(\mathrm{PhBP}_{3}\right)\left(\mathrm{C}_{2} \mathrm{H}_{4}\right)_{2}(\mathrm{H})\right]^{+}\left([\mathbf{1 0 a}]^{+}\right)$were found 542 to be higher in enthalpy than the corresponding $\beta$-agostic/ethyl 543 species. This noteworthy result for rhodium chemistry is well 544 explained when taking into account the steric pressure exerted 545 by the bulkier $\mathrm{PhBP}_{3}{ }^{-}$ligand in comparison to other systems 546 that have been studied. As noted earlier, small variations of 547 electronic and steric factors can control the strength of the $\beta$ 548 agostic interaction and will therefore determine the stability of 549 the insertion products relative to the hydrido-ethylene species. 550 Moreover, the stronger this interaction is, the more easily the 551 transformation into the rhodium hydride olefin counterpart 552 occurs. Finally, other olefins such as styrene also insert into the $553 \mathrm{Rh}-\mathrm{H}$ bond of complex $[\mathbf{1}]^{+}$, as deduced from exsy 554 experiments and DFT calculations. We believe that these 555 findings could help in the development of new complexes 556 suitable for $\mathrm{C}-\mathrm{H}$ bond functionalization and related reactions.

\section{ASSOCIATED CONTENT}

\section{S Supporting Information}

559 The Supporting Information is available free of charge on the 560 ACS Publications website at DOI: 10.1021/acs.organo561 met.6b00036.

$\begin{array}{ll}562 & \text { Experimental details (PDF) } \\ 563 & X, Y, Z \text { coordinates for DFT-calculated intermediates and } \\ 564 & \text { transition states (XYZ) }\end{array}$

\section{$565 \square$ AUTHOR INFORMATION}

\section{Corresponding Author}

567 *E-mail: ctejel@unizar.es.

\section{Present Address}

${ }_{569}^{\dagger}$ A.M.G.: School of Chemistry, University of Nottingham 570 University Park, Nottingham, NG7 2RD, U.K.

571 Notes

572 The authors declare no competing financial interest.

\section{ACKNOWLEDGMENTS}

574 The generous financial support from MICINN/FEDER 575 (Project CTQ2011-22516), MINECO/FEDER (Project 576 CTQ2014-53033-P), and Gobierno de Aragón/FSE (GA/ 577 FSE, Inorganic Molecular Architecture Group, E70) is 578 gratefully acknowledged. A.M.G. thanks GA/FSE for a 579 fellowship. This article is dedicated to the memory of Prof. 580 Roberto A. Sánchez-Delgado, a pioneer in chemistry, a brave 581 fighter and an excellent friend that encouraged to one of us 582 (C.T.) to overcome our common illness.

\section{$583 \square$ REFERENCES}

584 (1) Selected papers and reviews: (a) Masarwa, A.; Weber, M.; 585 Sarpong, R. J. Am. Chem. Soc. 2015, 137, 6327-6334. (b) Topczewski, 586 J. J.; Sanford, M. S. Chem. Sci. 2015, 6, 70-76. (c) Ebe, Y.; Nishimura, 587 T. J. Am. Chem. Soc. 2015, 137, 5899-5902. (d) Dateer, R. B.; Chang, 588 S. J. Am. Chem. Soc. 2015, 137, 4908-4911. (e) Gandeepan, P.; 589 Cheng, C.-H. Chem. - Asian J. 2015, 10, 824-838. (f) Yang, L.; Huang, 590 H. Chem. Rev. 2015, 115, 3468-3517. (g) Wang, Z.; Kuninobu, Y.; 591 Kanai, M. J. Am. Chem. Soc. 2015, 137, 6140-6143. (h) Ackermann, L. 592 Acc. Chem. Res. 2014, 47, 281-295. (i) Tsurugi, H.; Yamamoto, K.; 593 Nagae, H.; Kaneko, H.; Mashima, K. Dalton Trans. 2014, 43, 2331594 2343. (j) Campos, J.; Kundu, S.; Pahls, D. R.; Brookhart, M.; 595 Carmona, E.; Cundari, T. R. J. Am. Chem. Soc. 2013, 135, 1217-1220. (k) Poverenov, E.; Milstein, D. Top. Organomet. Chem. 2013, 40, 21- 596 48. (1) Lee, S. H.; Gorelsky, S. I.; Nikonov, G. I. Organometallics 2013, 597 32, 6599-6604. (m) Engle, K. M.; Mei, T.-S.; Wasa, M.; Yu, J.-Q. Acc. 598 Chem. Res. 2012, 45, 788-802. (n) Gunanathan, C.; Milstein, D. Acc. 599 Chem. Res. 2011, 44, 588-602. (o) Cho, S. H.; Kim, J. Y.; Kwak, J.; 600 Chang, S. Chem. Soc. Rev. 2011, 40, 5068-5083. (p) Wencel-Delord, 601 J.; Dröge, T.; Liu, F.; Glorius, F. Chem. Soc. Rev. 2011, 40, 4740-4761. 602 (q) Ackermann, L. Chem. Rev. 2011, 111, 1315-1345. (r) Colby, D. 603 A.; Bergman, R. G.; Ellman, J. A. Chem. Rev. 2010, 110, 624-655. 604 (s) Perutz, R. N.; Sabo-Etienne, S. Angew. Chem., Int. Ed. 2007, 46, 605 2578-2592. (t) Clot, E.; Eisenstein, O.; Jones, W. D. Proc. Natl. Acad. 606 Sci. U. S. A. 2007, 104, 6939-6944. (u) Chen, G. S.; Labinger, J. A.; 607 Bercaw, J. E. Proc. Natl. Acad. Sci. U. S. A. 2007, 104, 6915-6920. 608 (v) Bernskoetter, W. H.; Schauer, C. K.; Goldberg, K. I.; Brookhart, M. 609 Science 2009, 326, 553-556. (w) Crabtree, R. H. J. Organomet. Chem. 610 2004, 689, 4083-4091. (x) Hall, C.; Perutz, R. N. Chem. Rev. 1996, 611 96, 3125-3146.

612

(2) (a) Sieffert, N.; Réocreux, R.; Lorusso, P.; Cole-Hamilton, D. J.; 613 Bühl, M. Chem. - Eur. J. 2014, 20, 4141-4155. (b) Grellier, M.; Sabo- 614 Etienne, S. Chem. Commun. 2012, 48, 34-42. (c) Haibach, M. C.; 615 Kundu, S.; Brookhart, M.; Goldman, A. S. Acc. Chem. Res. 2012, 45, 616 947-958. (d) Choi, J.; MacArthur, A. H. R.; Brookhart, M.; Goldman, 617 A. S. Chem. Rev. 2011, 111, 1761-1779. (e) Gruver, B. C.; Adams, J. 618 J.; Warner, S. J.; Arulsamy, N.; Roddick, D. M. Organometallics 2011, 619 30, 5133-5140.

(3) Brookhart, M.; Green, M. L. H. J. Organomet. Chem. 1983, 250, 621 395-408.

(4) For leading references and revisions: (a) Shaw, P. A.; Phillips, J. 623 M.; Newman, C. P.; Clarkson, G. J.; Rourke, J. P. Chem. Commun. 624 2015, 51, 8365-8368. (b) Schmidbaur, H.; Raubenheimer, H. G.; 625 Dobrzańska, L. Chem. Soc. Rev. 2014, 43, 345-380. 626 (c) Saßmannshausen, J. Dalton Trans. 2012, 41, 1919-1923. 627 (d) Montag, M.; Efremenko, I.; Diskin-Posner, Y.; Ben-David, Y.; 628 Martin, J. M. L.; Milstein, D. Organometallics 2012, 31, 505-512. 629 (e) Scherer, W.; Herz, V.; Brück, A.; Hauf, C.; Reiner, F.; 630 Altmannshofer, S.; Leusser, D.; Stalke, D. Angew. Chem., Int. Ed. 631 2011, 50, 2845-2849. (f) Scherer, W.; Wolstenholme, D. J.; Herz, V.; 632 Eickerling, G.; Brück, A.; Benndorf, P.; Roesky, P. W. Angew. Chem., 633 Int. Ed. 2010, 49, 2242-2246. (g) Lein, M. Coord. Chem. Rev. 2009, 634 253, 625-634. (h) Etienne, M.; McGrady, J. E.; Maseras, F. Coord. 635 Chem. Rev. 2009, 253, 635-646. (i) Brookhart, M.; Green, M. L. H.; 636 Parkin, G. Proc. Natl. Acad. Sci. U. S. A. 2007, 104, 6908-6914. 637 (j) Clot, E.; Eisenstein, O. Struct. Bonding (Berlin, Ger.) 2004, 113, 1- 638 36. (k) Scherer, W.; McGrady, G. S. Angew. Chem., Int. Ed. 2004, 43, 639 1782-1806. (1) Niu, S.; Hall, M. B. Chem. Rev. 2000, 100, 353-405. 640 (m) Crabtree, R. H. Angew. Chem., Int. Ed. Engl. 1993, 32, 789-805. 641 (n) Brookhart, M.; Green, M. L. H.; Wong, L. L. Prog. Inorg. Chem. 642 1988, 36, 1-124.

(5) (a) Dunlop-Brière, A. F.; Baird, M. C.; Budzelaar, P. H. M. 644 Organometallics 2015, 34, 2356-2368. (b) Talarico, G.; Budzelaar, P. 645 H. M. Organometallics 2014, 33, 5974-5982. (c) Guo, N.; Stern, C. L.; 646 Marks, T. J. J. Am. Chem. Soc. 2008, 130, 2246-2261. (d) Grubbs, R. 647 H.; Coates, G. W. Acc. Chem. Res. 1996, 29, 85-93. 648

(6) See for example: (a) Balcells, D.; Clot, E.; Eisenstein, O. Chem. 649 Rev. 2010, 110, 749-823. (b) Häller, L. J. L.; Page, M. J.; Macgregor, 650 S. A.; Mahon, M. F.; Whittlesey, M. K. J. Am. Chem. Soc. 2009, 131, 651 4604-4605. (c) Chaplin, A. B.; Poblador-Bahamonde, A. I.; Sparkes, 652 H. A.; Howard, J. A. K.; Macgregor, S. A.; Weller, A. S. Chem. 653 Commun. 2009, 244-246. (d) Toner, A.; Matthes, J.; Gründemann, S.; 654 Limbach, H.-H.; Chaudret, B.; Clot, E.; Sabo-Etienne, S. Proc. Natl. 655 Acad. Sci. U. S. A. 2007, 104, 6945-6950. (e) Lersch, M.; Tilset, M. 656 Chem. Rev. 2005, 105, 2471-2526. (f) Li, X.; Appelhans, L. N.; Faller, 657 J. W.; Crabtree, R. H. Organometallics 2004, 23, 3378-3387. 658 (g) Labinger, J. A.; Bercaw, J. E. Nature 2002, 417, 507-514. 659 (h) Toner, A. J.; Gründemann, S.; Clot, E.; Limbach, H.-H.; 660 Donnadieu, B.; Sabo-Etienne, S.; Chaudret, B. J. Am. Chem. Soc. 661 2000, 122, 6777-6778. (i) Shilov, A. E.; Shul'pin, G. B. Chem. Rev. 662 1997, 97, 2879-2932. 
664 (7) (a) Walter, M. D.; White, P. S.; Brookhart, M. Chem. Commun. 665 2009, 6361-6363. (b) Walter, M. D.; Moorhouse, R. A.; Urbin, S. A.; 666 White, P. S.; Brookhart, M. J. Am. Chem. Soc. 2009, 131, 9055-9069. 667 (8) (a) Dunlop-Brière, A. F.; Budzelaar, P. H. M.; Baird, M. C. 668 Organometallics 2012, 31, 1591-1594. (b) Pantazis, D. A.; McGrady, J. 669 E.; Besora, M.; Maseras, F.; Etienne, M. Organometallics 2008, 27, 670 1128-1134. (c) Casey, C. P.; Tunge, J. A.; Lee, T.-Y.; Fagan, M. A. J. 671 Am. Chem. Soc. 2003, 125, 2641-2651.

672 (9) Van der Eide, E. F.; Yang, P.; Bullock, R. M. Angew. Chem., Int. 673 Ed. 2013, 52, 10190-10194.

674 (10) Ikeda, Y.; Takano, K.; Kodama, S.; Ishii, Y. Chem. Commun. 675 2013, 49, 11104-11106. (b) Sauriol, F.; Sonnenberg, J. F.; Chadder, S. 676 J.; Dunlop-Brière, A. F.; Baird, M. C.; Budzelaar, P. H. M. J. Am. Chem. 677 Soc. 2010, 132, 13357-13370.

678 (11) (a) Evans, M. E.; Li, T.; Jones, W. D. J. Am. Chem. Soc. 2010, 679 132, 16278-16284. (b) Steinke, T.; Shaw, B. K.; Jong, H.; Patrick, B. 680 O.; Fryzuk, M. D.; Green, J. C. J. Am. Chem. Soc. 2009, 131, 10461681 10466. (c) Ateşin, T. A.; Li, T.; Lachaize, S.; Brennessel, W. W.; 682 García, J. J.; Jones, W. D. J. Am. Chem. Soc. 2007, 129, 7562-7569. 683 (12) (a) Campos, J.; Ortega-Moreno, L.; Conejero, S.; Peloso, R.; 684 López-Serrano, J.; Maya, C.; Carmona, E. Chem. - Eur. J. 2015, 21, 685 8883-8896. (b) Campos, J.; Peloso, R.; Carmona, E. Angew. Chem., 686 Int. Ed. 2012, 51, 8255-8258. (c) Crosby, S. H.; Clarkson, G. J.; 687 Rourke, J. P. Organometallics 2011, 30, 3603-3609. (d) Rivada688 Wheelaghan, O.; Donnadieu, B.; Maya, C.; Conejero, S. Chem. - Eur. J. 689 2010, 16, 10323-10326. (e) Frech, C. M.; Shimon, L. J. W.; Milstein, 690 D. Organometallics 2009, 28, 1900-1908. (f) Lavallo, V.; Canac, Y.; 691 DeHope, A.; Donnadieu, B.; Bertrand, G. Angew. Chem., Int. Ed. 2005, 692 44, 7236-7239. (g) Stambuli, J. P.; Incarvito, C. D.; Bühl, M.; 693 Hartwig, J. F. J. Am. Chem. Soc. 2004, 126, 1184-1194. (h) Ingleson, 694 M. J.; Mahon, M. F.; Weller, A. S. Chem. Commun. 2004, 2398-2399. 695 (i) Baratta, W.; Stoccoro, S.; Doppiu, A.; Herdtweck, E.; Zucca, A.; 696 Rigo, P. Angew. Chem., Int. Ed. 2003, 42, 105-108.

697 (13) (a) Saßmannshausen, J. Dalton Trans. 2011, 40, 136-141. 698 (b) Crosby, S. H.; Clarkson, G. J.; Rourke, J. P. J. Am. Chem. Soc. 2009, 699 131, 14142-14143. (c) Baratta, W.; Da Ros, P.; Del Zotto, A.; Sechi, 700 A.; Zangrando, E.; Rigo, P. Angew. Chem., Int. Ed. 2004, 43, 3584701 3588. (d) Baratta, W.; Mealli, C.; Herdtweck, E.; Ienco, A.; Mason, S. 702 A.; Rigo, P. J. Am. Chem. Soc. 2004, 126, 5549-5562. (e) Baratta, W.; 703 Herdtweck, E.; Rigo, P. Angew. Chem., Int. Ed. 1999, 38, 1629-1631. 704 (f) Huang, D.; Streib, W. E.; Bollinger, J. C.; Caulton, K. G.; Winter, R. 705 F.; Scheiring, T. J. Am. Chem. Soc. 1999, 121, 8087-8097. (g) Cooper, 706 A. C.; Streib, W. E.; Eisenstein, O.; Caulton, K. G. J. Am. Chem. Soc. 707 1997, 119, 9069-9070.

708 (14) See for example: (a) Dunlop-Brière, A. F.; Baird, M. C.; 709 Budzelaar, P. H. M. J. Am. Chem. Soc. 2013, 135, 17514-17527. 710 (b) Findlater, M.; Cartwright-Sykes, A.; White, P. S.; Schauer, C. K.; 711 Brookhart, M. J. Am. Chem. Soc. 2011, 133, 12274-12284 and 712 references therein. (c) Sydora, O. L.; Kilyanek, S. M.; Jordan, R. F. J. 713 Am. Chem. Soc. 2007, 129, 12952-12953. (d) Faller, J. W.; Fontaine, 714 P. P. Organometallics 2007, 26, 1738-1743. (e) Chirik, P. J.; Dalleska, 715 N. F.; Henling, L. M.; Bercaw, J. E. Organometallics 2005, 24, 27897162794 and references therein. (f) Chirik, P. J.; Bercaw, J. E. 717 Organometallics 2005, 24, 5407-5423. (g) Tempel, D. J.; Brookhart, 718 M. Organometallics 1998, 17, 2290-2296. (h) Spencer, J. L.; Mhinzi, 719 G. S. J. Chem. Soc., Dalton Trans. 1995, 3819-3824. (i) Casey, C. P.; 720 Yi, C. S. Organometallics 1991, 10, 33-35.

721 (15) (a) Ortuño, M. A.; Vidossich, P.; Ujaque, G.; Conejero, S.; 722 Lledós, A. Dalton Trans. 2013, 42, 12165-12172. (b) Xu, R.; Klatt, G.; 723 Wadepohl, H.; Köppel, H. Inorg. Chem. 2010, 49, 3289-3296 and 724 references therein. (c) Fooladi, E.; Krapp, A.; Sekiguchi, O.; Tilset, M.; 725 Uggerud, E. Dalton Trans. 2010, 39, 6317-6326. (d) Mitoraj, M. P.; 726 Michalak, A.; Ziegler, T. Organometallics 2009, 28, 3727-3733. 727 (e) Collins, S.; Ziegler, T. Organometallics 2007, 26, 6612-6623. 728 (f) Han, Y.; Deng, L.; Ziegler, T. J. Am. Chem. Soc. 1997, 119, 5939729 5945. (g) Deng, L.; Woo, T. K.; Cavallo, L.; Margl, P. M.; Ziegler, T. J. 730 Am. Chem. Soc. 1997, 119, 6177-6186.

731 (16) (a) Valente, A.; Mortreux, A.; Visseaux, M.; Zinck, P. Chem. Rev. 732 2013, 113, 3836-3857. (b) Shiotsuki, M.; White, P. S.; Brookhart, M.;
Templeton, J. L. J. Am. Chem. Soc. 2007, 129, 4058-4067. (c) Jenkins, 733 J. C.; Brookhart, M. J. Am. Chem. Soc. 2004, 126, 5827-5842. 734 (d) Leatherman, M. D.; Svejda, S. A.; Johnson, L. K.; Brookhart, M. J. 735 Am. Chem. Soc. 2003, 125, 3068-3081. (e) Daugulis, O.; Brookhart, 736 M.; White, P. S. Organometallics 2003, 22, 4699-4704. (f) Shultz, L. 737 H.; Tempel, D. J.; Brookhart, M. J. Am. Chem. Soc. 2001, 123, 11539- 738 11555. (g) Shultz, L. H.; Brookhart, M. Organometallics 2001, 20, 739 3975-3982. (h) Tempel, D. J.; Johnson, L. K.; Huff, R. L.; White, P. 740 S.; Brookhart, M. J. Am. Chem. Soc. 2000, 122, 6686-6700. (i) Ittel, S. 741 D.; Johnson, L. K.; Brookhart, M. Chem. Rev. 2000, 100, 1169-1203. 742 (j) Svejda, S. A.; Johnson, L. K.; Brookhart, M. J. Am. Chem. Soc. 1999, 743 121, 10634-10635. (k) Johnson, L. K.; Killian, C. M.; Brookhart, M. J. 744 Am. Chem. Soc. 1995, 117, 6414-6415. (1) Guo, Z.; Swenson, D. C.; 745 Jordan, R. F. Organometallics 1994, 13, 1424-1432. (m) Ogasawara, 746 M.; Saburi, M. Organometallics 1994, 13, 1911-1917. (n) Burger, B. J.; 747 Thompson, M. E.; Cotter, W. D.; Bercaw, J. E. J. Am. Chem. Soc. 1990, 748 112, 1566-1577. (o) Burger, B. J.; Santarsiero, B. D.; Trimmer, M. S.; 749 Bercaw, J. E. J. Am. Chem. Soc. 1988, 110, 3134-3146. (p) Doherty, N. 750 M.; Bercaw, J. E. J. Am. Chem. Soc. 1985, 107, 2670-2682. 751

(17) (a) Conroy-Lewis, F. M.; Mole, L.; Redhouse, A. D.; Litster, S. 752 A.; Spencer, J. L. J. Chem. Soc., Chem. Commun. 1991, 1601-1603. 753 (b) Brookhart, M.; Lincoln, D. M.; Volpe, A. F., Jr.; Schmidt, G. F. 754 Organometallics 1989, 8, 1212-1218.

(18) (a) Ledford, J.; Shultz, C. S.; Gates, D. P.; White, P. S.; 756 DeSimone, J. M.; Brookhart, M. Organometallics 2001, 20, 5266-5276. 757 (b) Carr, N.; Mole, L.; Orpen, A. G.; Spencer, J. L. J. Chem. Soc., 758 Dalton Trans. 1992, 2653-2662. (c) Mole, L.; Spencer, J. L.; Carr, N.; 759 Orpen, A. G. Organometallics 1991, 10, 49-52.

(19) (a) Pudasaini, B.; Janesko, B. G. Organometallics 2014, 33, 84- 761 93. (b) Hasanayn, F.; Achord, P.; Braunstein, P.; Magnier, H. J.; 762 Krogh-Jespersen, K.; Goldman, A. S. Organometallics 2012, 31, 4680- 763 4692.

(20) Creve, S.; Oevering, H.; Coussens, B. B. Organometallics 1999, 765 18, 1967-1978.

(21) Roe, C. J. Am. Chem. Soc. 1983, 105, 7770-7771. 767

(22) (a) Brookhart, M.; Hauptman, E.; Lincoln, D. M. J. Am. Chem. 768 Soc. 1992, 114, 10394-10401. (b) Brookhart, M.; Lincoln, D. M.; 769 Bennett, M. A.; Pelling, S. J. Am. Chem. Soc. 1990, 112, 2691-2694. 770 (c) Brookhart, M.; Lincoln, D. M. J. Am. Chem. Soc. 1988, 110, 8719- 771 8720. (d) Werner, H.; Feser, R. J. Organomet. Chem. 1982, 232, 351- 772 370. (e) Werner, H.; Feser, R. Angew. Chem., Int. Ed. Engl. 1979, 18, 773 $157-158$.

(23) (a) Pisareva, I. V.; Dolgushin, F. M.; Godovikov, I. A.; 775 Chizhevsky, I. T. Inorg. Chem. Commun. 2008, 11, 1202-1204. 776 (b) Hodson, B. E.; McGrath, T. D.; Stone, F. G. A. Organometallics 777 2005, 24, 1638-1646. (c) Speckman, D. M.; Knobler, C. B.; 778 Hawthorne, M. F. Organometallics 1985, 4, 1692-1694. 779

(24) Haibach, M. C.; Wang, D. Y.; Emge, T. J.; Krogh-Jespersen, K.; 780 Goldman, A. S. Chem. Sci. 2013, 4, 3683-3692.

(25) (a) Tejel, C.; Geer, A. M.; Jiménez, S.; López, J. A.; Ciriano, M. 782 A. Organometallics 2012, 31, 2895-2906. (b) Turculet, L.; Feldman, J. 783 D.; Tilley, T. D. Organometallics 2004, 23, 2488-2502.

(26) Tejel, C.; Ciriano, M. A.; Jiménez, S.; Passarelli, V.; López, J. A. 785 Angew. Chem., Int. Ed. 2008, 47, 2093-2096. 786 (27) Geer, A. M.; Julián, A.; López, J. A.; Ciriano, M. A.; Tejel, C. 787 Chem. - Eur. J. 2014, 20, 2732-2736.

(28) Geer, A. M.; Tejel, C.; López, J. A.; Ciriano, M. A. Angew. Chem., 789 Int. Ed. 2014, 53, 5614-5618.

(29) Jiménez, S.; López, J. A.; Ciriano, M. A.; Tejel, C.; Martínez, A.; 791 Sánchez-Delgado, R. A. Organometallics 2009, 28, 3193-3202. 792

(30) Tejel, C.; Ciriano, M. A.; Passarelli, V. Chem. - Eur. J. 2011, 17, 793 91-95.

(31) Pregosin, P. S. NMR in Organometallic Chemistry; Wiley-VCH: 795 Weinheim, 2012.

(32) Fernández, I.; Martínez-Viviente, E.; Pregosin, P. S. Inorg. Chem. 797 2005, 44, 5509-5513.

(33) (a) Brayshaw, S. K.; Green, J. C.; Kociok-Köhn, G.; Sceats, E. L.; 799 Weller, A. S. Angew. Chem., Int. Ed. 2006, 45, 452-456. (b) Scott, N. 800 
801 M.; Dorta, R.; Stevens, E. D.; Correa, A.; Cavallo, L.; Nolan, S. P. J. $802 \mathrm{Am}$. Chem. Soc. 2005, 127, 3516-3526.

803 (34) Ehlers, A. W.; Böhme, M.; Dapprich, S.; Gobbi, A.; Höllwarth, 804 A.; Jonas, V.; Köhler, K. F.; Stegmann, R.; Veldkamp, A.; Frenking, G. 805 Chem. Phys. Lett. 1993, 208, 111-114.

806 (35) The opening of the angle $\mathrm{Rh}-\mathrm{C}^{\alpha}-\mathrm{C}^{\beta}$ is a consequence of the 807 shift of the carbon $\mathrm{C}^{\beta}$ from nitrogen, from a distance of $2.639 \AA$ 808 (associated with an angle $\mathrm{Rh}-\mathrm{C}^{\alpha}-\mathrm{C}^{\beta}$ of $104.8^{\circ}$, in $[3 \mathbf{b}]^{+}$) to $3.113 \AA$ $809\left(\mathrm{Rh}-\mathrm{C}^{\alpha}-\mathrm{C}^{\beta}\right.$ of $104.8^{\circ}$, in $\left.[3 \mathrm{c}]^{+}\right)$. Sum of van der Waals radii of $\mathrm{C}$ and $810 \mathrm{~N}=3.25 \AA$.

811 (36) Energy for agostic interactions is expected to be from modest to 812 low $\left(\leq 15 \mathrm{kcal} \mathrm{mol}^{-1}\right)$; see for example refs $1 \mathrm{i}, 1 \mathrm{x}, 6 \mathrm{~g}$, and 9 .

813 (37) gNMR V5.0.6.0 by P. H. M. Budzelaar, published by Cherwell 814 Scientific Publishing, Copyright 2006 Ivory soft.

815 (38) The sole exceptions to this general trend are the complexes $816\left[\mathrm{Rh}\left(\mathrm{C}_{5} \mathrm{Me}_{5}\right)\left(\mathrm{C}_{2} \mathrm{H}_{4}\right)\left(\mathrm{CH}_{2} \mathrm{CH}_{2}-\mu-\mathrm{H}\right)\right]^{+}$(ref 22b) and the allyl deriva817 tive $\left[\mathrm{Rh}\left(\mathrm{C}_{5} \mathrm{Me}_{5}\right)\left(\mathrm{C}_{6} \mathrm{H}_{9}\right)\right]^{+}$. Bennett, M. A.; McMahon, I. J.; Pelling, S.; 818 Brookhart, M.; Lincoln, D. M. Organometallics 1992, 11, 127-138. 